\title{
Evaluation of geochemical records as a paleoenvironmental proxy in the hypercalcified demosponge Astrosclera willeyana
}

Ryuji Asami ${ }^{1 *}$, Akira Kinjo ${ }^{2}$, Daiki Ohshiro ${ }^{2}$, Tohru Naruse ${ }^{3}$, Masaru Mizuyama ${ }^{4}$, Ryu Uemura ${ }^{5}$, Ryuichi Shinjo², Yuji Ise ${ }^{6}$, Yoshihisa Fujita ${ }^{7}$ and Takashi Sakamaki ${ }^{8}$

\begin{abstract}
The geochemistry of the calcium carbonates of marine organisms is an excellent proxy for reconstruction of the paleoceanographic history. However, previous studies of hypercalcified demosponges (sclerosponges) are considerably fewer than those of corals, foraminifers, and bivalves. Here, we investigated stable oxygen $\left(\delta^{18} \mathrm{O}\right)$ and carbon $\left(\delta^{13} \mathrm{C}\right)$ isotopes and minor and trace element $(\mathrm{Mg}, \mathrm{Sr}, \mathrm{Ba}, \mathrm{Pb}$, and $\mathrm{U})$ to Ca ratios of 36 living sclerosponges (Astrosclera willeyana) collected from Kume Island in the Ryukyu Islands, southwestern Japan, to evaluate the utility of geochemistry as a paleoenvironmental proxy. The $\delta^{18} \mathrm{O}, \delta^{13} \mathrm{C}$, and $\mathrm{Sr} / \mathrm{Ca}$ deviations of the coevally precipitated skeleton were extremely small and almost constant at all skeletal portions, strongly suggesting that within-skeletal variations in the chemical components are negligibly small for non-symbiotic sclerosponges. Mean $\delta^{18} \mathrm{O}, \delta^{13} \mathrm{C}$, and $\mathrm{Sr} / \mathrm{Ca}$ values $(N=36)$, falling within a quite narrow range, showed no significant evidence for intraspecific (interspecimen) variations in the sclerosponges. The sclerosponges $\delta^{18} \mathrm{O}$ and $\delta^{13} \mathrm{C}$ were consistent with those of the aragonites precipitated in isotopic equilibrium with seawater at the growth site. The sclerosponge Sr/Ca was close to that of inorganically precipitated aragonite, and the estimated partition coefficient of 1.1 (almost unity) is identical to previously reported values for different species (Ceratoporella nicholsoni). Consequently, these results suggest that $A$. willeyana sclerosponge, having little vital effects on the geochemistry, is a robust indicator of paleocean environments (seawater $\delta^{18} \mathrm{O}$, temperature, and dissolved inorganic carbon $\delta^{13} \mathrm{C}$ ). Further, our evaluation study documents that sclerosponges living in deeper ocean environments can support the reconstruction of spatial and vertical paleoceanographic changes in conjunction with coral proxy records. The sclerosponge U/Ca showed little within-skeletal and intraspecific variations, but the heterogeneity and individual difference of the $\mathrm{Mg} / \mathrm{Ca}, \mathrm{Ba} / \mathrm{Ca}$, and $\mathrm{Pb} / \mathrm{Ca}$ were relatively large, the reasons of which still remain unresolved.
\end{abstract}

Keywords: Sclerosponge, Astrosclera willeyana, Oxygen and carbon isotopic composition, Minor and trace elements, Isotope equilibrium, Paleoenvironmental proxy

\footnotetext{
* Correspondence: ryuji.asami.b5@tohoku.ac.jp

${ }^{1}$ Institute of Geology and Paleontology, Graduate School of Science, Tohoku

University, Aobayama, Sendai 980-8578, Japan

Full list of author information is available at the end of the article
}

\section{Springer Open}

(c) The Author(s). 2020 Open Access This article is licensed under a Creative Commons Attribution 4.0 International License, which permits use, sharing, adaptation, distribution and reproduction in any medium or format, as long as you give appropriate credit to the original author(s) and the source, provide a link to the Creative Commons licence, and indicate if changes were made. The images or other third party material in this article are included in the article's Creative Commons licence, unless indicated otherwise in a credit line to the material. If material is not included in the article's Creative Commons licence and your intended use is not permitted by statutory regulation or exceeds the permitted use, you will need to obtain permission directly from the copyright holder. To view a copy of this licence, visit http://creativecommons.org/licenses/by/4.0/. 


\section{Introduction}

The hypercalcified demosponges ("sclerosponge" hereinafter), members of the earliest branching metazoan taxon (Porifera), have been dominant reef-building marine organisms throughout the Phanerozoic (e.g., Vacelet 1985; Reitner and Engeser 1987; Wood 1990; Reitner 1992). The taxon Astrosclera is present in the fossil record from the Late Triassic (Vacelet 1979, 1985). In modern coral reefs, the sclerosponges can be found in cryptic niches of low-light environments, unlike zooxanthellate scleractinian corals (e.g., Wörheide 1998). Sclerosponges, commonly mushroom-shaped in form, deposit a $\mathrm{CaCO}_{3}$ skeleton at a very slow growth rate of mostly less than about $2 \mathrm{~mm}$ /year and can grow for up to several hundred years (e.g., Benavides and Druffel 1986; Böhm et al. 1996; Reitner and Gautret 1996; Wörheide et al. 1997; Wörheide 1998; Swart et al. 2002; Fallon et al. 2003; Grottoli et al. 2010).

To elucidate the processes underpinning climate change and global warming, environmental proxy archives such as trees, sediments, and corals for documenting air and sea surface temperature variation over the last millennia are needed (PAGES $2 \mathrm{k}$ Consortium 2013; Abram et al. 2016). The stable oxygen $\left(\delta^{18} \mathrm{O}\right)$ and carbon $\left(\delta^{13} \mathrm{C}\right)$ isotope records of sclerosponges are a useful proxy for reconstructing seawater temperature and salinity (e.g., Wörheide 1998; Böhm et al. 2000; Moore et al. 2000; Rosenheim et al. 2005a) and dissolved inorganic carbon $\delta^{13} \mathrm{C}$ of seawater (e.g., Böhm et al. 1996; Swart et al. 2010) for the past. Results of previous studies have shown that, like corals, the $\delta^{18} \mathrm{O}$ and $\delta^{13} \mathrm{C}$ values of sclerosponges have respectively reflected interannual climate variability (Swart et al. 2002; Grottoli 2006; Grottoli et al. 2010; Wu and Grottoli 2010) and increasing fossil fuel $\mathrm{CO}_{2}$ in seawater (Böhm et al. 2002; Swart et al. 2010). Moreover, other minor and trace elements and isotopes can be a proxy for monitoring ocean environments and chemistry (e.g., Lazareth et al. 2000; Fallon et al. 2005; Rosenheim et al. 2005b; Ohmori et al. 2014). Some studies showed that sclerosponge strontium/ calcium $(\mathrm{Sr} / \mathrm{Ca})$ can offer a potential for paleotemperature determination of seawater (e.g., Rosenheim et al. 2004; Waite et al. 2018).

Importantly, sclerosponges can live in environments with less sunlight (ex. reef caves and overhangs) and at greater water depths of up to several hundred meters in the Indo-Pacific tropical regions (e.g., Hartman 1980) and in the Atlantic and Caribbean regions (e.g., Druffel and Benavides 1986; Böhm et al. 1996), unlike zooxanthellate corals and giant clams living in shallow coral reefs. For that reason, their skeletal chemistry can be useful for elucidating vertical variations of physical and chemical parameters of seawater and generating their several-century-long time series that overlap with and extend beyond the instrumental climate data. Nevertheless, sclerosponge-based reconstruction studies are extremely few (especially in the North Pacific) relative to those of other marine $\mathrm{CaCO}_{3}$ organisms such as corals, foraminifers, and mollusks. Furthermore, evaluation and calibration studies of sclerosponges for fidelity as a paleoenvironmental proxy are few and they were only based on time series analyses along the growth direction (Böhm et al. 2000; Rosenheim et al. 2005b, 2009). Therefore, distribution (homogeneity/heterogeneity) and intraspecific difference of chemical composition in the sclerosponge skeleton should be evaluated for further robust application to paleoenvironmental reconstruction.

We investigated 36 specimens of living sclerosponges collected in Kume Island, southwestern part of Japan in the North Pacific to clarify (1) within-skeletal variations in the $\delta^{18} \mathrm{O}, \delta^{13} \mathrm{C}$, and elements/Ca ratios (magnesium/ $\mathrm{Ca}(\mathrm{Mg} / \mathrm{Ca}), \mathrm{Sr} / \mathrm{Ca}$, barium/Ca $(\mathrm{Ba} / \mathrm{Ca})$, lead/Ca $(\mathrm{Pb} / \mathrm{Ca})$, and uranium/Ca $(\mathrm{U} / \mathrm{Ca}))$ and (2) their intraspecific variations (individual difference $=$ inter-specimen variations). In addition, to evaluate the fidelity as a paleoenvironmental proxy, we compared the isotopic values of the sclerosponge samples to theoretically calculated values of aragonites precipitated close to isotope equilibrium with seawater at the living site and estimated partition coefficients for elements/Ca between seawater and aragonitic skeleton. Knowledge acquired through the results of our evaluation study can contribute to the expansion of applications of multi-proxy reconstructions for climate and ocean environmental changes and can provide insight into a better understanding of calcium carbonate biomineralization for marine organisms.

\section{Materials and methods}

\section{Study site and environment}

The study site $\left(26^{\circ} 20^{\prime} 12-17^{\prime \prime} \mathrm{N}, 126^{\circ} 43^{\prime} 40-49^{\prime \prime} \mathrm{E}\right)$ is located off the western coast of Kume Island in the Ryukyu Islands, southwestern Japan (Fig. 1). The climate of this region is subtropical, with atmospheric temperatures of $17-29{ }^{\circ} \mathrm{C}$ and an annual mean of $23{ }^{\circ} \mathrm{C}$ (Japan Meteorological Agency 2016). The average annual precipitation is ca. $2100 \mathrm{~mm} / \mathrm{year}$. The warm Kuroshio current (the western North Pacific current) flows into the East China Sea and passes northeastward along the Ryukyu Islands. It allows the development of coral reefs with a high bio-diversity at Kume Island (e.g., Naruse et al. 2012).

In situ seawater temperature and salinity at the study site in water depths of 34-40 m were measured every $1 \mathrm{~h}$ from the 5th of October 2015 through the 13th of November 2016 using data loggers (Infinity CTW; JFE Advantech Co., Ltd. and HOBO Tidbit v2; Onset Computer Corp.). The observation data were calibrated with actual temperature and salinity measurements of seawater collected at the study site using a calibration thermometer and a conductivity meter (CM-41X: DKK- 


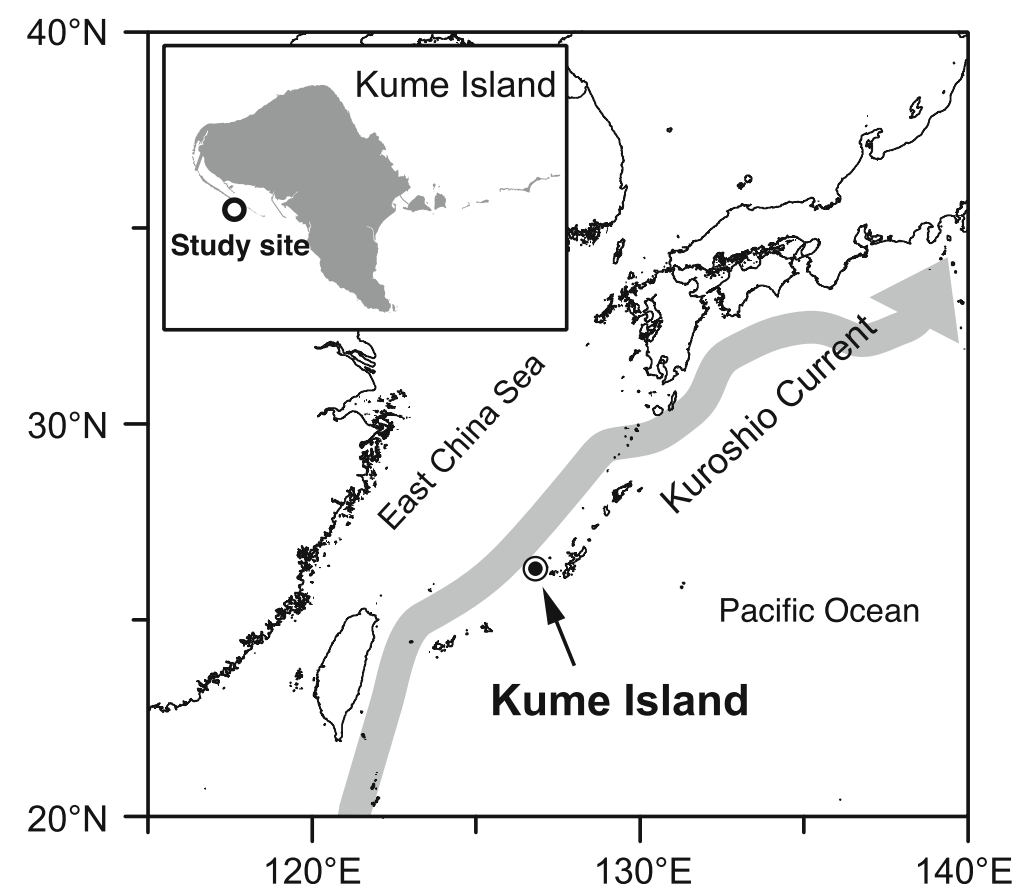

Fig. 1 Maps showing Kume Island and study site locations

TOA Corp.). The in situ data for 2015-2016 are fundamentally consistent with monthly average data at a depth of $30 \mathrm{~m}$, available from the Japan Oceanographic Data Center (JODC) for $1906-2003\left(26^{\circ}-27^{\circ} \mathrm{N}, 126^{\circ}-\right.$ $127^{\circ}$ E; http://www.jodc.go.jp/) (Fig. 2). The seawater temperature and salinity vary respectively, as $20^{\circ} \mathrm{C}-$ $31^{\circ} \mathrm{C}$ and $33.6-35.0$ (psu) with annual means of $25.4^{\circ} \mathrm{C}$ and 34.6 (psu).

\section{Samples}

The hypercalcified demosponges (Astrosclera willeyana Lister 1900) examined in this study were growing on the ceiling or wall in dark submarine caves, crevasses, or overhung of reef outer edge. In October 2015 and November 2016, 36 living sclerosponge samples were collected by scuba diving. Specifically, 6 samples (KMJ40), 4 samples (KMJ-34), and 26 samples (KMJ-38) were collected respectively at water depths of $40 \mathrm{~m}, 34 \mathrm{~m}$, and $38 \mathrm{~m}$ (Table 1 and Fig. 3). The surfaces of samples are mostly light-to-dark brown and/or orange. The samples, which were from $5.4 \mathrm{~mm} \times 5.0 \mathrm{~mm} \times 2.5 \mathrm{~mm}$ to 24.9 $\mathrm{mm} \times 18.0 \mathrm{~mm} \times 11.6 \mathrm{~mm}$, were rinsed three times ultrasonically with milli- $\mathrm{Q}$ water (resistance $=18.2 \mathrm{~m} \Omega$; Millipore Corp.) and were then dried in a desiccator.

To check the mineralogy and preservation state of the skeleton, five selected sclerosponges (KMJ-38-14, KMJ38-20, KMJ-38-22, KMJ-38-25, and KMJ-38-26) were examined using X-ray diffraction (XRD) analysis and scanning electron microscopy (SEM) (Fig. 4). At the University of the Ryukyus, XRD analysis was conducted using a multipurpose XRD device (RINT Ultima/PC; Rigaku Corp.) to test for the presence of calcite. Powdered samples were mounted on well-cleaned glass slides with $\mathrm{HCl}$, ethanol, and milli- $\mathrm{Q}$ water and were analyzed using $\mathrm{Cu} K \alpha$ radiation $(40 \mathrm{kV}, 30 \mathrm{~mA})$ by scanning from 20 to $37^{\circ}$ at a $2 \theta$ angle at $0.02^{\circ}$ steps. SEM imaging of the skeleton was conducted using a microscope (TM3030; Hitachi High-Tech. Corp.).

\section{Stable isotope analyses}

For stable isotope analyses, powdered subsamples (1-20 subsamples per sclerosponge) were taken from the skeleton surface along the $X$-axis (= long axis) and $Y$-axis (= short axis) directions (see Fig. 4), to evaluate withinskeleton variations in the isotope values. The top of the sample is regarded as the coordinate origin $(X=0, Y=0)$. A subsample $(\Phi, 1 \mathrm{~mm}$; depth, ca. $1.5 \mathrm{~mm})$ was taken at intervals of $1-4 \mathrm{~mm}$ from the coevally precipitated skeleton using a pre-cleaned diamond drill. The common skeletal growth rates of $A$. willeyana scleroponges are estimated to be about $0.2-1.9 \mathrm{~mm} /$ year (e.g., Wörheide 1998; Moore et al. 2000; Fallon and Guilderson 2005; Fallon et al. 2005; Grottoli et al. 2010). The tissue layer in A. willeyana can occupy upwards of about $5 \mathrm{~mm}$ and the time between initial deposition and secondary infilling of aragonite skeleton appears to be several years (Fallon et al. 2005; Allison et al. 2012). Furthermore, the skeletal density of $A$. willeyana increases gradually with depth. That in the surface living zone is about half that of inner structures, which is indicative of continual thickening of 


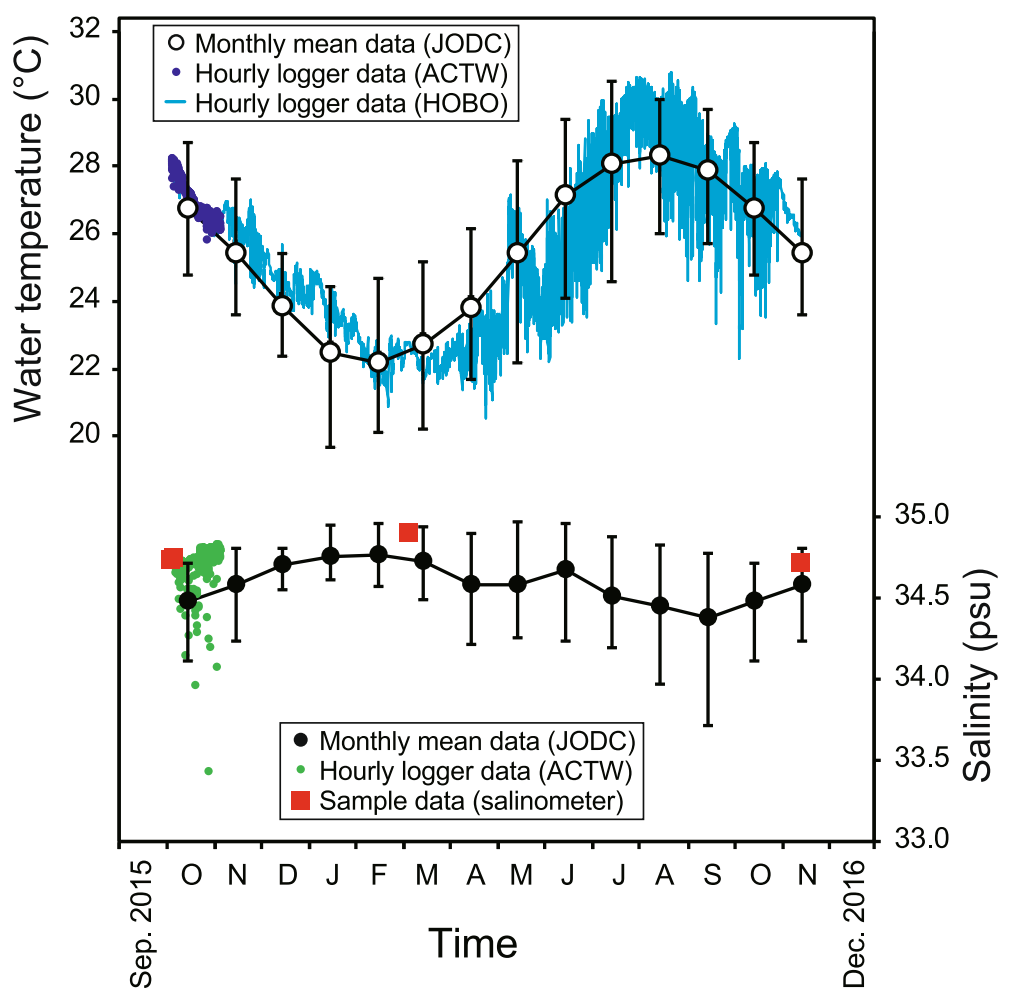

Fig. 2 Monthly mean climatology and logging data of seawater temperature and salinity at the study site. Data are derived from the Japan Oceanographic Data Center (JODC) for 1906-2003 (26-27 N, 126 $-127^{\circ}$ E; http://www.jodc.go.jp/) and in situ observations made during October 2015 to November 2016 using loggers in this study. Error bars represent monthly maximum and minimum values in the past. Salinity of seawater samples collected at the site was also measured for cross-validation

aragonite throughout the living tissue layer (Fallon et al. 2005). Considering such characteristics of skeletal growth, the subsampling portion $(\Phi, \sim 1 \mathrm{~mm}$; depth, $\sim 1.5 \mathrm{~mm})$ probably corresponds to an increment during about a few years, assumed to be the years 2013-2016 in this study.

Stable oxygen $\left(\delta^{18} \mathrm{O}\right)$ and carbon $\left(\delta^{13} \mathrm{C}\right)$ isotope analyses of calcium carbonate $(0.14-0.16 \mathrm{mg})$ were conducted using a continuous flow isotope ratio mass spectrometer attached to a Gasbench II and a GC-PAL auto-sampler (Delta V Advantage; ThermoFisher Scientific Inc.) at the University of the Ryukyus, following the method presented by Asami et al. (2015). The seawater $\delta^{18} \mathrm{O}$ was measured using a cavity ring-down spectroscopy (CRDS L2130-i; Picarro Inc.) at the University of the Ryukyus, following the method reported by Uemura et al. (2012). Isotopic ratios were reported in the conventional $\delta$ notation relative to Vienna Pee Dee Belemnite (VPDB) for carbonate and Vienna Standard Mean Ocean Water $(\mathrm{VSMOW})$ for seawater. External precision $(1 \sigma)$ throughout the entire analysis was $\pm 0.07 \% \circ\left(\delta^{18} \mathrm{O}\right)$ and $\pm 0.05 \%$ o $\left(\delta^{13} \mathrm{C}\right)$ for carbonate and $\pm 0.08 \%$ o $\left(\delta^{18} \mathrm{O}\right)$ for seawater. Accuracy of the measurements of sclerosponge samples was evaluated based on replicates of GSJ/AIST JCp-1 (aragonite; Okai et al. 2004), yielding average $\delta^{18} \mathrm{O}$ and $\delta^{13} \mathrm{C}$ values of $-4.65 \pm 0.07 \%$ and $-1.59 \pm 0.06 \%$
$(N=42)$, which show excellent agreement with previously reported values of $-4.71 \%$ and - $1.63 \%$ (Nakayama et al. 2008), respectively.

\section{Elements/Ca analyses}

Elements/Ca ratios $(\mathrm{Mg} / \mathrm{Ca}, \mathrm{Sr} / \mathrm{Ca}, \mathrm{Ba} / \mathrm{Ca}, \mathrm{Pb} / \mathrm{Ca}, \mathrm{U} / \mathrm{Ca})$ were analyzed using an inductively coupled plasma-mass spectrometer (XSeries II, Thermo Fisher Scientific) at the University of the Ryukyus, basically following the method reported by Asami et al. (2009, 2013). Each sclerosponge powder sample $(\sim 0.15 \mathrm{mg})$ was dissolved in $4.5 \mathrm{~mL}$ of $0.5 \mathrm{~mol} / \mathrm{L}$ high-purity $\mathrm{HNO}_{3}$ diluted with ultrapure Milli-Q water. Each seawater sample of $125 \mu \mathrm{L}$ was diluted 80 times with high-purity $\mathrm{HNO}_{3}$ and ultrapure Milli-Q water. Internal standard elements (Sc, Y, and $\mathrm{Yb}$ ) were added to all of the solutions to produce equal concentrations to control matrix effect and to correct for instrumental noise. Solutions were analyzed for ${ }^{24} \mathrm{Mg},{ }^{43} \mathrm{Ca},{ }^{44} \mathrm{Ca},{ }^{45} \mathrm{Sc},{ }^{87} \mathrm{Sr},{ }^{88} \mathrm{Sr},{ }^{89} \mathrm{Y},{ }^{137} \mathrm{Ba},{ }^{138} \mathrm{Ba},{ }^{172} \mathrm{Yb}$, ${ }^{208} \mathrm{~Pb}$, and ${ }^{238} \mathrm{U}$. Measurements were conducted in triplicate. Calibrations of the five gravimetric standard solutions yielded high correlation coefficients of $r>0.99998$ for $\mathrm{Ca}, \mathrm{Mg}$, and $\mathrm{Sr}$ and of $r>0.99995$ for $\mathrm{Ba}, \mathrm{Pb}$, and $\mathrm{U}$. A reference solution, gravimetrically matched to the $\mathrm{Ca}$ concentration of the average sclerosponge sample 
Table 1 Details of sclerosponge samples and analytical results of geochemistry

\begin{tabular}{|c|c|c|c|c|c|c|c|c|c|c|c|c|c|c|c|c|c|c|c|c|}
\hline \multirow[t]{2}{*}{$\begin{array}{l}\text { Sample } \\
\text { ID }\end{array}$} & \multirow[t]{2}{*}{$\begin{array}{l}\text { Collection } \\
\text { Date }\end{array}$} & \multirow{2}{*}{$\begin{array}{l}\text { Water } \\
\text { Depth } \\
\text { (m) }\end{array}$} & \multicolumn{3}{|l|}{ Size } & \multirow[t]{2}{*}{$N$} & \multicolumn{2}{|c|}{$\delta^{13} \mathrm{C}(\% 0)$} & \multicolumn{2}{|c|}{$\delta^{18} \mathrm{O}(\%)$} & \multicolumn{2}{|c|}{$\begin{array}{l}\mathrm{Mg} / \mathrm{Ca} \\
(\mathrm{mmol} / \mathrm{mol})\end{array}$} & \multicolumn{2}{|c|}{$\begin{array}{l}\mathrm{Sr} / \mathrm{Ca} \\
(\mathrm{mmol} / \mathrm{mol})\end{array}$} & \multicolumn{2}{|c|}{$\begin{array}{l}\mathrm{Ba} / \mathrm{Ca} \\
(\mu \mathrm{mol} / \mathrm{mol})\end{array}$} & \multicolumn{2}{|c|}{$\begin{array}{l}\mathrm{Pb} / \mathrm{Ca} \\
(\mu \mathrm{mol} / \mathrm{mol})\end{array}$} & \multicolumn{2}{|c|}{$\begin{array}{l}\mathrm{U} / \mathrm{Ca} \\
(\mu \mathrm{mol} / \mathrm{mol})\end{array}$} \\
\hline & & & $\begin{array}{l}X \\
(\mathrm{~mm})\end{array}$ & $\begin{array}{l}Y \\
(\mathrm{~mm})\end{array}$ & $\begin{array}{l}\mathrm{H} \\
(\mathrm{mm})\end{array}$ & & Avg. & $\begin{array}{l}S D \\
(1 \sigma)\end{array}$ & Avg. & $\begin{array}{l}\mathrm{SD} \\
(1 \sigma)\end{array}$ & $\overline{\text { Avg. }}$ & $\begin{array}{l}S D \\
(1 \sigma)\end{array}$ & $\overline{\text { Avg. }}$ & $\begin{array}{l}\mathrm{SD} \\
(1 \sigma)\end{array}$ & Avg. & $\begin{array}{l}S D \\
(1 \sigma)\end{array}$ & $\overline{\text { Avg. }}$ & $\begin{array}{l}S D \\
(1 \sigma)\end{array}$ & $\overline{\text { Avg. }}$ & $\begin{array}{l}\text { SD } \\
(1 \sigma)\end{array}$ \\
\hline $\begin{array}{l}\text { KMJ-40- } \\
1\end{array}$ & 6-Oct-15 & 40 & 9.4 & 8.8 & 6.0 & 9 & 3.49 & 0.07 & -1.08 & 0.07 & 1.45 & 0.36 & 9.42 & 0.17 & 0.59 & 0.70 & 0.45 & 0.28 & 3.26 & 0.04 \\
\hline $\begin{array}{l}\text { KMJ-40- } \\
2\end{array}$ & & & 11.4 & 7.9 & 4.8 & 8 & 3.40 & 0.05 & -1.16 & 0.10 & 1.49 & 0.64 & 9.36 & 0.11 & 1.06 & 0.64 & 0.51 & 0.17 & 3.23 & 0.03 \\
\hline $\begin{array}{l}\text { KMJ-40- } \\
3\end{array}$ & & & 12.3 & 11.8 & 5.5 & 9 & 3.43 & 0.05 & -1.00 & 0.17 & 2.11 & 0.61 & 9.41 & 0.11 & 1.39 & 0.76 & 0.71 & 0.17 & 3.13 & 0.06 \\
\hline $\begin{array}{l}\text { KMJ-40- } \\
4\end{array}$ & & & 19.0 & 15.5 & 8.9 & 14 & 3.42 & 0.06 & -1.00 & 0.11 & 1.59 & 0.25 & 9.52 & 0.15 & 1.90 & 1.02 & 0.63 & 0.15 & 3.25 & 0.02 \\
\hline $\begin{array}{l}\text { KMJ-40- } \\
5\end{array}$ & & & 24.9 & 18.0 & 11.6 & 13 & 3.47 & 0.08 & -1.01 & 0.13 & 1.85 & 0.36 & 9.42 & 0.16 & 2.74 & 0.77 & N/A & & 3.24 & 0.06 \\
\hline $\begin{array}{l}\text { KMJ-40- } \\
6\end{array}$ & & & 21.0 & 18.6 & 12.6 & 14 & 3.51 & 0.08 & -0.75 & 0.12 & 1.33 & 0.38 & 9.58 & 0.19 & 2.97 & 0.69 & N/A & & 3.21 & 0.07 \\
\hline $\begin{array}{l}\text { KMJ-34- } \\
1\end{array}$ & 7-Oct-15 & 34 & 10.3 & 10.2 & 5.9 & 13 & 3.51 & 0.05 & -0.98 & 0.07 & 1.45 & 0.47 & 9.63 & 0.13 & 1.96 & 0.44 & 0.71 & 0.11 & 3.17 & 0.04 \\
\hline $\begin{array}{l}\text { KMJ-34- } \\
2\end{array}$ & & & 12.4 & 11.3 & 6.0 & 12 & 3.45 & 0.09 & -0.88 & 0.06 & 1.26 & 0.23 & 9.76 & 0.09 & 2.06 & 0.40 & 0.81 & 0.13 & 3.12 & 0.04 \\
\hline $\begin{array}{l}\text { KMJ-34- } \\
3\end{array}$ & & & 13.9 & 10.8 & 6.8 & 14 & 3.42 & 0.12 & -1.02 & 0.09 & 1.47 & 0.39 & 9.52 & 0.09 & 2.04 & 0.44 & 0.74 & 0.12 & 3.17 & 0.07 \\
\hline $\begin{array}{l}\text { KMJ-34- } \\
4\end{array}$ & & & 15.2 & 13.8 & 11.4 & 17 & 3.44 & 0.07 & -1.07 & 0.12 & 1.61 & 0.37 & 9.43 & 0.14 & 1.86 & 0.43 & 0.73 & 0.12 & 3.27 & 0.05 \\
\hline $\begin{array}{l}\text { ALL (KM. } \\
\text { CL }\end{array}$ & $\mathrm{JJ}-34$ and -40 & 0): 95\% & & & & & $\begin{array}{l}3.45 \\
0.02\end{array}$ & & $\begin{array}{l}-0.995 \\
0.072\end{array}$ & & $\begin{array}{l}1.560 \\
0.160\end{array}$ & & $\begin{array}{l}9.503 \\
0.077\end{array}$ & & $\begin{array}{l}1.857 \\
0.451\end{array}$ & & $\begin{array}{l}0.663 \\
0.086\end{array}$ & & $\begin{array}{l}3.205 \\
0.033\end{array}$ & \\
\hline $\begin{array}{l}\text { KMJ-38- } \\
1\end{array}$ & 13-Nov-16 & 38 & 14.7 & 13.2 & 8.8 & 16 & 3.41 & 0.05 & -0.98 & 0.06 & 1.31 & 0.32 & 9.15 & 0.17 & 1.44 & 0.94 & N/A & & 3.27 & 0.14 \\
\hline $\begin{array}{l}\text { KMJ-38- } \\
2\end{array}$ & & & 17.7 & 12.5 & 10.5 & 18 & 3.40 & 0.05 & -1.01 & 0.16 & 1.29 & 0.34 & 9.27 & 0.28 & 1.47 & 1.11 & N/A & & 3.24 & 0.12 \\
\hline $\begin{array}{l}\text { KMJ-38- } \\
3\end{array}$ & & & 5.4 & 5.0 & 2.5 & 1 & 3.37 & & -1.17 & & 2.14 & & 9.26 & & N/A & & N/A & & 3.36 & \\
\hline $\begin{array}{l}\text { KMJ-38- } \\
4\end{array}$ & & & 6.0 & 5.7 & 2.0 & 1 & 3.48 & & -0.95 & & 1.40 & & 9.29 & & N/A & & 0.08 & & 3.27 & \\
\hline $\begin{array}{l}\text { KMJ-38- } \\
5\end{array}$ & & & 6.0 & 6.0 & 3.0 & 1 & 3.44 & & -0.99 & & 1.45 & & 9.55 & & N/A & & 0.53 & & 3.42 & \\
\hline $\begin{array}{l}\text { KMJ-38- } \\
6\end{array}$ & & & 7.2 & 6.9 & 3.5 & 5 & 3.36 & 0.02 & -0.89 & 0.10 & 1.78 & 0.51 & 9.43 & 0.28 & 0.59 & 1.07 & N/A & & 3.29 & 0.10 \\
\hline $\begin{array}{l}\text { KMJ-38- } \\
7\end{array}$ & & & 7.8 & 7.1 & 3.0 & 5 & 3.38 & 0.03 & -0.95 & 0.08 & 1.67 & 0.17 & 9.45 & 0.16 & 0.75 & 0.99 & N/A & & 3.40 & 0.15 \\
\hline $\begin{array}{l}\text { KMJ-38- } \\
8\end{array}$ & & & 7.7 & 7.2 & 4.0 & 5 & 3.34 & 0.05 & -1.02 & 0.09 & 1.33 & 0.20 & 9.35 & 0.12 & 0.31 & 0.29 & N/A & & 3.54 & 0.08 \\
\hline $\begin{array}{l}\text { KMJ-38- } \\
9\end{array}$ & & & 9.7 & 8.7 & 4.0 & 5 & 3.38 & 0.04 & -1.00 & 0.09 & 0.95 & 0.10 & 9.74 & 0.08 & N/A & & 2.32 & 1.64 & 3.35 & 0.06 \\
\hline $\begin{array}{l}\text { KMJ-38- } \\
10\end{array}$ & & & 10.0 & 9.9 & 6.0 & 5 & 3.41 & 0.05 & -0.93 & 0.03 & 1.07 & 0.12 & 9.80 & 0.15 & 0.43 & 0.97 & 0.98 & 0.75 & 3.34 & 0.14 \\
\hline $\begin{array}{l}\text { KMJ-38- } \\
11\end{array}$ & & & 11.0 & 10.3 & 7.0 & 15 & 3.40 & 0.06 & -1.09 & 0.11 & 0.90 & 0.06 & 9.33 & 0.09 & 0.12 & 0.33 & 2.53 & 1.16 & 3.37 & 0.10 \\
\hline $\begin{array}{l}\text { KMJ-38- } \\
12\end{array}$ & & & 11.4 & 8.9 & 5.1 & 12 & 3.42 & 0.05 & -0.99 & 0.08 & 0.96 & 0.28 & 9.41 & 0.08 & 0.09 & 0.31 & 3.53 & 1.37 & 3.30 & 0.07 \\
\hline $\begin{array}{l}\text { KMJ-38- } \\
13\end{array}$ & & & 12.8 & 8.9 & 7.3 & 11 & 3.44 & 0.05 & -0.94 & 0.06 & 1.03 & 0.18 & 9.51 & 0.09 & 0.09 & 0.20 & 4.55 & 2.49 & 3.48 & 0.07 \\
\hline $\begin{array}{l}\text { KMJ-38- } \\
14\end{array}$ & & & 12.3 & 10.8 & 7.0 & 14 & 3.37 & 0.04 & -0.90 & 0.05 & 1.08 & 0.12 & 9.73 & 0.40 & 2.41 & 0.85 & 3.20 & 1.36 & 3.11 & 0.07 \\
\hline KMJ-38- & & & 12.7 & 11.8 & 6.4 & 13 & 3.40 & 0.03 & -1.06 & 0.09 & 1.14 & 0.22 & 9.44 & 0.25 & 1.59 & 1.14 & 3.82 & 2.70 & 3.18 & 0.06 \\
\hline
\end{tabular}




\begin{tabular}{|c|c|c|c|c|c|c|c|c|c|c|c|c|c|c|c|c|c|c|c|c|}
\hline \multirow[t]{2}{*}{$\begin{array}{l}\text { Sample } \\
\text { ID }\end{array}$} & \multirow[t]{2}{*}{$\begin{array}{l}\text { Collection } \\
\text { Date }\end{array}$} & \multirow{2}{*}{$\begin{array}{l}\text { Water } \\
\text { Depth } \\
\text { (m) }\end{array}$} & \multicolumn{3}{|l|}{ Size } & \multirow[t]{2}{*}{$N$} & \multicolumn{2}{|c|}{$\delta^{13} \mathrm{C}(\%)$} & \multicolumn{2}{|c|}{$\delta^{18} \mathrm{O}(\%)$} & \multicolumn{2}{|c|}{$\begin{array}{l}\mathrm{Mg} / \mathrm{Ca} \\
(\mathrm{mmol} / \mathrm{mol})\end{array}$} & \multicolumn{2}{|c|}{$\begin{array}{l}\mathrm{Sr} / \mathrm{Ca} \\
(\mathrm{mmol} / \mathrm{mol})\end{array}$} & \multicolumn{2}{|c|}{$\begin{array}{l}\mathrm{Ba} / \mathrm{Ca} \\
(\mu \mathrm{mol} / \mathrm{mol})\end{array}$} & \multicolumn{2}{|c|}{$\begin{array}{l}\mathrm{Pb} / \mathrm{Ca} \\
(\mu \mathrm{mol} / \mathrm{mol})\end{array}$} & \multicolumn{2}{|c|}{$\begin{array}{l}\mathrm{U} / \mathrm{Ca} \\
(\mu \mathrm{mol} / \mathrm{mol})\end{array}$} \\
\hline & & & $\begin{array}{l}X \\
(\mathrm{~mm})\end{array}$ & $\begin{array}{l}Y \\
(\mathrm{~mm})\end{array}$ & $\begin{array}{l}\mathrm{H} \\
(\mathrm{mm})\end{array}$ & & Avg. & $\begin{array}{l}\text { SD } \\
(1 \sigma)\end{array}$ & Avg. & $\begin{array}{l}\mathrm{SD} \\
(1 \sigma)\end{array}$ & Avg. & $\begin{array}{l}S D \\
(10) \\
\end{array}$ & Avg. & $\begin{array}{l}S D \\
(10) \\
\end{array}$ & Avg. & $\begin{array}{l}S D \\
(10) \\
\end{array}$ & Avg. & $\begin{array}{l}S D \\
(10) \\
\end{array}$ & Avg. & $\begin{array}{l}\text { SD } \\
(1 \sigma)\end{array}$ \\
\hline \multicolumn{21}{|l|}{15} \\
\hline $\begin{array}{l}\text { KMJ-38- } \\
16\end{array}$ & & & 15.9 & 15.5 & 8.8 & 16 & 3.39 & 0.06 & -1.17 & 0.05 & 1.02 & 0.21 & 9.28 & 0.09 & 1.20 & 0.82 & 3.01 & 1.55 & 3.22 & 0.06 \\
\hline $\begin{array}{l}\text { KMJ-38- } \\
17\end{array}$ & & & 17.1 & 15.1 & 8.8 & 14 & 3.41 & 0.05 & -1.07 & 0.11 & 1.19 & 0.31 & 9.56 & 0.15 & 0.84 & 0.95 & N/A & 3.80 & 3.21 & 0.07 \\
\hline $\begin{array}{l}\text { KMJ-38- } \\
18\end{array}$ & & & 15.6 & 12.8 & 8.0 & 12 & 3.34 & 0.06 & -1.12 & 0.12 & 1.09 & 0.16 & 9.36 & 0.25 & 1.86 & 1.03 & 2.24 & 0.87 & 3.16 & 0.05 \\
\hline $\begin{array}{l}\text { KMJ-38- } \\
19\end{array}$ & & & 14.8 & 13.6 & 9.0 & 15 & 3.37 & 0.06 & -0.94 & 0.07 & 1.22 & 0.49 & 9.30 & 0.17 & 2.24 & 0.45 & 1.50 & 0.44 & 3.22 & 0.05 \\
\hline $\begin{array}{l}\text { KMJ-38- } \\
20\end{array}$ & & & 18.2 & 15.9 & 9.5 & 19 & 3.38 & 0.04 & -1.01 & 0.09 & 1.04 & 0.14 & 9.38 & 0.09 & 1.01 & 0.71 & N/A & 3.49 & 3.24 & 0.04 \\
\hline $\begin{array}{l}\text { KMJ-38- } \\
21\end{array}$ & & & 20.0 & 16.8 & 10.0 & 20 & 3.39 & 0.05 & -1.00 & 0.07 & 1.10 & 0.12 & 9.41 & 0.25 & 1.46 & 0.86 & 3.19 & 1.64 & 3.20 & 0.05 \\
\hline $\begin{array}{l}\text { KMJ-38- } \\
22\end{array}$ & & & 18.5 & 18.2 & 9.0 & 15 & 3.41 & 0.03 & -1.02 & 0.07 & 1.10 & 0.27 & 9.32 & 0.19 & 1.31 & 0.90 & 2.37 & 1.37 & 3.20 & 0.07 \\
\hline $\begin{array}{l}\text { KMJ-38- } \\
23\end{array}$ & & & 20.5 & 15.8 & 9.0 & 14 & 3.35 & 0.06 & -0.95 & 0.09 & 1.23 & 0.20 & 9.74 & 0.31 & 1.75 & 0.92 & 1.43 & 0.61 & 3.20 & 0.05 \\
\hline $\begin{array}{l}\text { KMJ-38- } \\
24\end{array}$ & & & 21.6 & 16.2 & 10.0 & 17 & 3.37 & 0.06 & -0.96 & 0.11 & 1.15 & 0.07 & 9.43 & 0.18 & 2.13 & 0.44 & 0.79 & 0.18 & 3.17 & 0.04 \\
\hline $\begin{array}{l}\text { KMJ-38- } \\
25\end{array}$ & & & 19.8 & 19.7 & 10.2 & 18 & 3.39 & 0.05 & -1.02 & 0.11 & 0.99 & 0.14 & 9.38 & 0.20 & 2.15 & 0.47 & 0.77 & 0.39 & 3.22 & 0.06 \\
\hline $\begin{array}{l}\text { KMJ-38- } \\
26\end{array}$ & & & 21.6 & 19.1 & 11.8 & 20 & 3.39 & 0.06 & -1.01 & 0.08 & 0.86 & 0.09 & 9.24 & 0.18 & 1.55 & 0.79 & 0.72 & 0.12 & 3.25 & 0.06 \\
\hline ALL (KM & J-38): 95\% & & & & & & $\begin{array}{l}3.392 \\
0.012\end{array}$ & & $\begin{array}{l}-1.006 \\
0.029\end{array}$ & & $\begin{array}{l}1.21 \\
0.11\end{array}$ & & $\begin{array}{l}9.428 \\
0.067\end{array}$ & & $\begin{array}{l}1.21 \\
0.31\end{array}$ & & $\begin{array}{l}2.086 \\
0.611\end{array}$ & & $\begin{array}{l}3.27 \\
0.041\end{array}$ & \\
\hline
\end{tabular}

solutions, was measured at intervals of three samples to correct for instrumental drift. Based on replicate measurements of the solution of aragonite reference material JCp-1 coral (Okai et al. 2002), external precisions for $\mathrm{Mg} / \mathrm{Ca}, \mathrm{Sr} / \mathrm{Ca}, \mathrm{Ba} / \mathrm{Ca}, \mathrm{Pb} / \mathrm{Ca}$, and $\mathrm{U} / \mathrm{Ca}$ determinations were better than $0.43 \%, 0.31 \%, 1.1 \%, 4.0 \%$, and $0.82 \%$ relative standard deviations $(N=150)$ and the measurement values of samples were calibrated using the widely accepted values of Hathorne et al. (2013).

\section{Results and discussion}

\section{Skeletal structures and preservation}

The results of XRD analysis indicate that the skeleton samples of Astrosclera willeyana consist exclusively of aragonite (> 99.9\%), with no detection of calcite. The SEM images of skeletal samples also reveal no evidence of the existence of calcite (Fig. 5). Skeletal aspects of our sclerosponge samples closely resemble those found in earlier studies (e.g., Wörheide 1998; Jackson et al. 2010; Gilis et al. 2013), clearly showing a typical macrostructure of reticulate skeletal organization with branches composed of aragonitic spherulitic structural elements (Ayling 1982; Reitner 1992; Allison et al. 2012). Pristine aragonite crystals were observed without evidence of diagenetic alteration such as overgrowth of inorganically precipitated secondary cements, traces of dissolution, or bioerosion. Consequently, these results indicate that $A$. willeyana samples used for this study can retain pristine skeletons with original values of isotope composition and elemental concentrations.

\section{Within-skeleton variations \\ Oxygen and carbon isotopes}

Biological carbonates are known to precipitate out of ${ }^{13} \mathrm{C}$ and ${ }^{18} \mathrm{O}$ equilibrium with seawater attributable to kinetic and metabolic isotope effects (e.g., McConnaughey 1998, 2003). For a photosynthetic scleractinian aragonitic coral with symbiotic algae, McConnaughey (1989) showed that the $\delta^{13} \mathrm{C}$ and $\delta^{18} \mathrm{O}$ variations $(1 \sigma)$ of the coeval skeletal increments were significantly different between sunshine side samples $( \pm 0.17 \%$ and $\pm 0.04 \%$, respectively) and shade side samples $( \pm 0.47 \%$ o and \pm $0.49 \%$, respectively). Furthermore, a strong positive correlation $(r=0.90)$ between coral $\delta^{13} \mathrm{C}$ and $\delta^{18} \mathrm{O}$ was found for the shade side. These results suggest that the isotopic composition is different depending on the skeletal portion of $\mathrm{CaCO}_{3}$ in photosynthetic corals. 


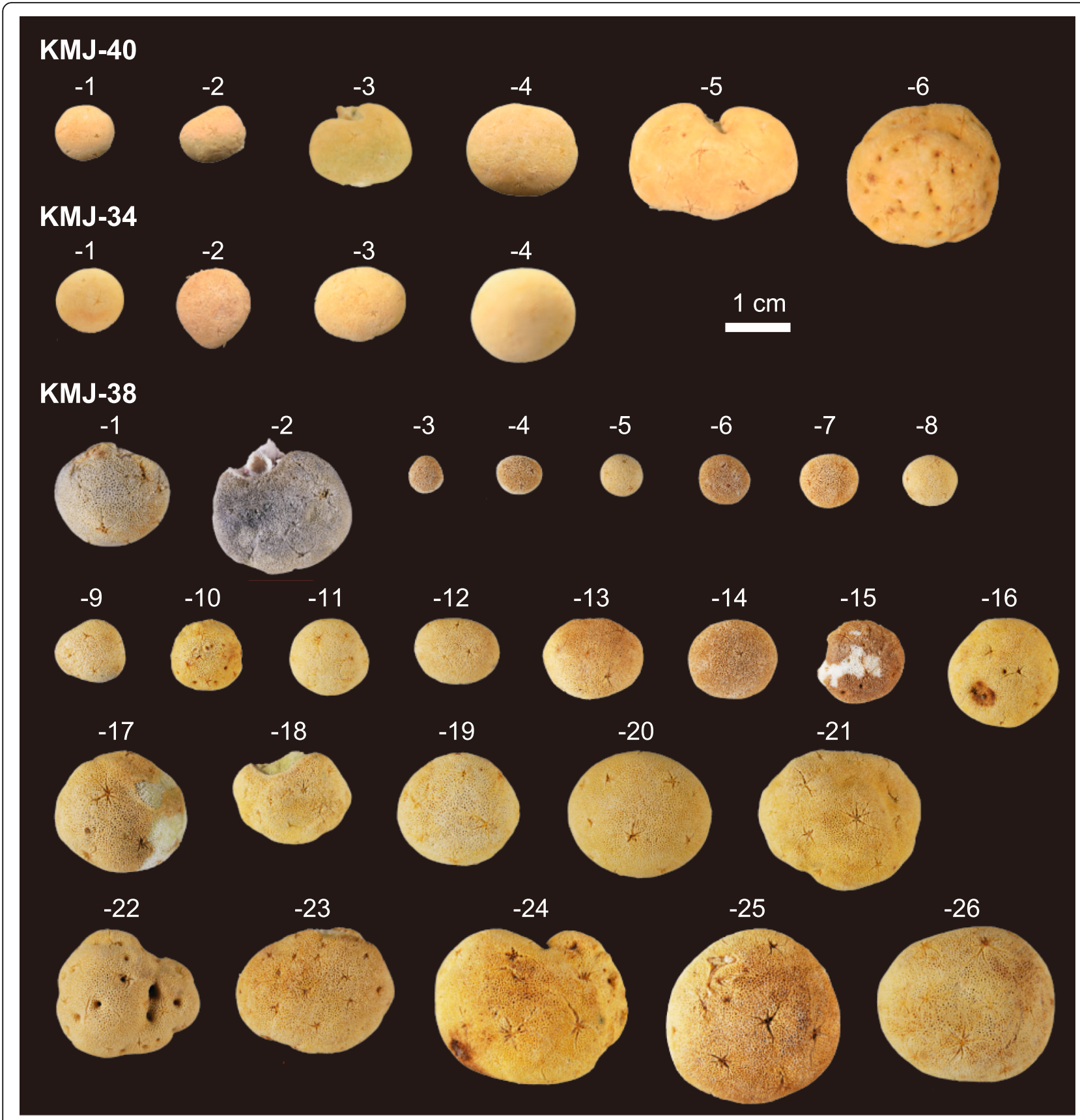

Fig. 3 Photographs of sclerosponge samples

The average and standard deviation $(1 \sigma)$ of $\delta^{13} \mathrm{C}$ and $\delta^{18} \mathrm{O}$ in an $A$. willeyana specimen were estimated from values of sub-samples $(N<20)$ collected at the coevally precipitated skeleton (Table 1; Fig. 4). The $\delta^{13} \mathrm{C}$ and $\delta^{18} \mathrm{O}$ records are almost similar among KMJ-40, KMJ34, and KMJ-38. The $\delta^{13} \mathrm{C}$ and $\delta^{18} \mathrm{O}$ variations (standard deviations, $1 \sigma$ ) of the coeval skeleton were quite small: from \pm 0.02 to $\pm 0.12 \%$ and from \pm 0.03 to $\pm 0.17 \%$, respectively. To identify within-skeletal variations of all samples, the respective deviations relative to the average (differences between isotopic values and the average) in an individual specimen are depicted in Fig. 6. The whole standard deviation $(2 \sigma)$ of the isotopic differences was small $\left( \pm 0.11 \%\right.$ for $\delta^{13} \mathrm{C}$ and $\pm 0.19 \%$ or $\left.\delta^{18} \mathrm{O}\right)$ and almost constant at all skeletal portions, with no significant variations and trends (Fig. 6). These results show that the within-skeletal variations in the isotopic composition are negligibly slight for the species $A$. willeyana.

The distribution of correlation coefficients among respective samples in within-skeleton showed little 


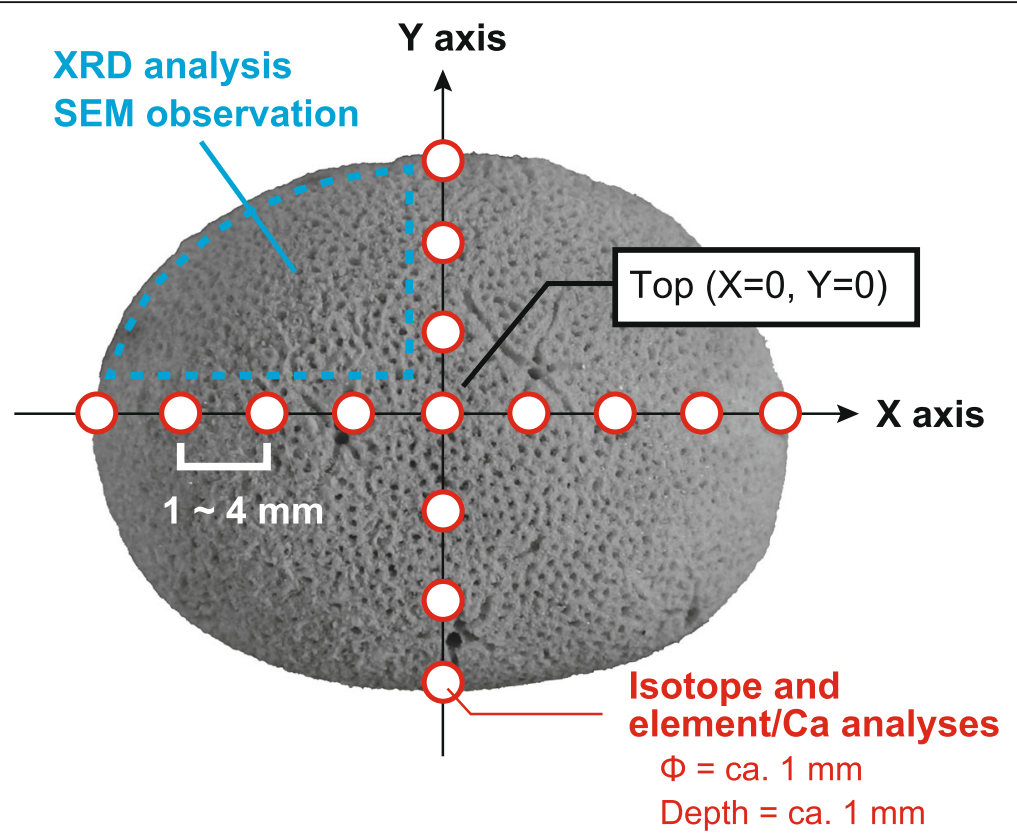

Fig. 4 Example showing the sub-sampling method conducted on a sclerosponge specimen. Subsamples for geochemical analyses (red) and for XRD analysis and SEM observation (blue) were collected

systematic relationships and trends (Fig. 7). Only 5 sclerosponge samples showed positive relations between the $\delta^{13} \mathrm{C}$ and $\delta^{18} \mathrm{O}$ with high $r$ values of $0.6-0.8$, but these are expected to be arbitrary in consideration of the very slight within-skeletal variation of $\pm 0.03-0.06 \%$ for $\delta^{13} \mathrm{C}$ and $\pm 0.08-0.11 \%$ for $\delta^{18} \mathrm{O}$ and considering analytical errors (Table 1). It is considered that the homogeneity of the isotopic composition in the coevally skeleton for $A$. willeyana is due to little kinetic fractionation effect because the species has no symbiont and a very slow growth rate of the $\mathrm{CaCO}_{3}$ precipitation.

\section{Elements/Ca ratios}

Despite $\delta^{13} \mathrm{C}$ and $\delta^{18} \mathrm{O}$ records, only a few studies have reported minor and trace elements/Ca ratios of sclerosponges (e.g., Fallon et al. 2005; Rosenheim et al. 2005b; Allison et al. 2012). The $\mathrm{Sr} / \mathrm{Ca}$ and U/Ca records in the coevally precipitated skeletons of $A$. willeyana samples are almost similar among KMJ-40, KMJ-34, and KMJ-38 (Table 1). Overall, the $\mathrm{Mg} / \mathrm{Ca}, \mathrm{Sr} / \mathrm{Ca}$, and $\mathrm{U} / \mathrm{Ca}$ variations $(1 \sigma)$ of the coeval skeleton were small, ranging respectively from \pm 0.06 to $\pm 0.64 \mathrm{mmol} / \mathrm{mol}, \pm 0.08$ to $\pm 0.40 \mathrm{mmol} /$ $\mathrm{mol}$, and from \pm 0.02 to $\pm 0.15 \mu \mathrm{mol} / \mathrm{mol}$. The sclerosponge $\mathrm{Ba} / \mathrm{Ca}$ and $\mathrm{Pb} / \mathrm{Ca}$ had large fluctuations with respective standard deviations of $\pm 0.20-1.14 \mu \mathrm{mol} / \mathrm{mol}$ and $\pm 0.11-3.80 \mu \mathrm{mol} / \mathrm{mol}$. The deviations $(2 \sigma)$ relative to the average for an individual were almost constant at all skeletal portions $( \pm 0.55 \mathrm{mmol} / \mathrm{mol}$ for $\mathrm{Mg} / \mathrm{Ca}, \pm 0.37 \mathrm{mmol} / \mathrm{mol}$ for $\mathrm{Sr} / \mathrm{Ca}, \pm 1.45 \mu \mathrm{mol} / \mathrm{mol}$ for $\mathrm{Ba} / \mathrm{Ca}, \pm 2.45 \mu \mathrm{mol} / \mathrm{mol}$ for
$\mathrm{Pb} / \mathrm{Ca}$, and $\pm 0.13 \mu \mathrm{mol} / \mathrm{mol}$ for $\mathrm{U} / \mathrm{Ca}$ ), with no significant variations and trends (Fig. 6). These results show that the elements are homogeneously distributed in coeval skeleton of $A$. willeyana sclerosponge, whereas the relative standard deviations of $\mathrm{Sr} / \mathrm{Ca}(3.9 \%)$ and $\mathrm{U} / \mathrm{Ca}(4.2 \%)$ were quite smaller than those of $\mathrm{Mg} / \mathrm{Ca}(45 \%), \mathrm{Ba} / \mathrm{Ca}(97 \%)$, and $\mathrm{Pb} /$ Ca (138\%), which can be partially caused by the difference in elemental concentrations and respective analytical errors. Therefore, our results suggest that the within-skeletal variations of $\mathrm{Sr} / \mathrm{Ca}$ and $\mathrm{U} / \mathrm{Ca}$ in $A$. willeyana sclerosponge are so slight as to be ignored.

The distribution of correlation coefficients among respective samples in within-skeleton showed little systematic relationships and trends, showing that most of the $r$ values fell within a range from -0.4 to 0.4 (Fig. 7). The relationships mostly explain only < $20 \%$ of the covariance among respective geochemical composition, thereby indicating that the within-skeletal geochemistry for $A$. willeyana can be less influenced by kinetic fractionation effect. It is known that sclerosponges are composed of two key crystal structures in the skeleton at a micro-scale resolution: fused aragonitic spherulites (formed intracellularly and fused together at the surface) and epitaxial backfill (deposited extracellularly at the base of the sponge tissue). Highresolution spatial analyses showed that elements/Ca ratios were highly variable in and among these structures (Allison et al. 2012), probably indicating a heterogeneity of chemical composition in the sclerosponge skeleton. 


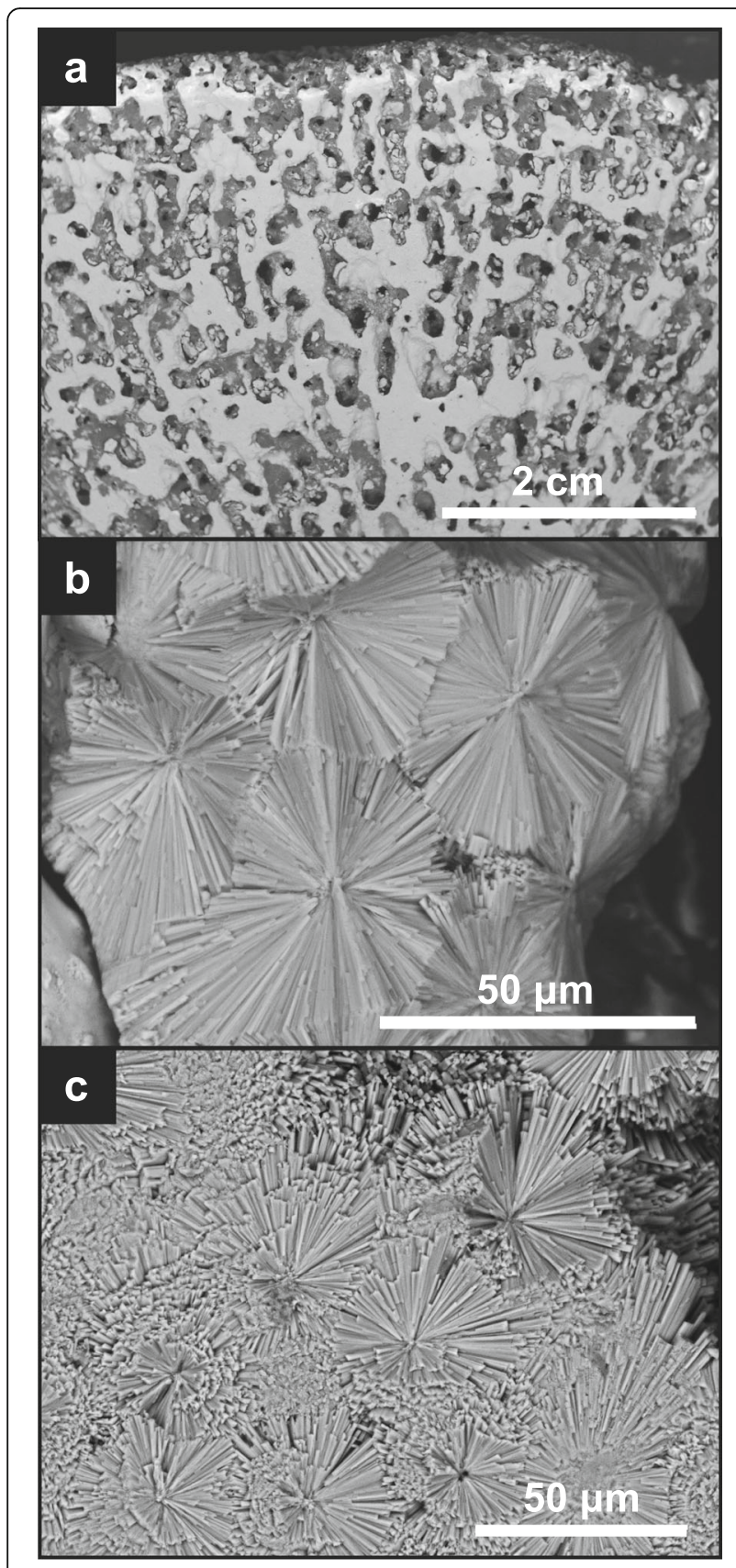

Fig. 5 Scanning electron micrograph images of sclerosponges. A well-preserved pristine aragonite skeleton is visible (a, b KMJ-38-14; c KMJ-38-25)

On the other hand, our data showed that withinskeletal $\mathrm{Sr} / \mathrm{Ca}$ and $\mathrm{U} / \mathrm{Ca}$ of $A$. willeyana sclerosponges were quite small and constant (Table 1 and Fig. 6). These suggest that the chemical components in the sclerosponge skeleton are commonly homogeneous at millimeter-scale resolution and annually resolved reconstruction of ocean environmental changes can be applied.

\section{Intraspecific variations}

\section{Oxygen and carbon isotopes}

The average $\delta^{13} \mathrm{C}\left(\delta^{18} \mathrm{O}\right)$ values of $A$. willeyana samples collected in October 2015 and November 2016 fell within quite narrow ranges from 3.40 to $3.51 \%$ (from 0.75 to $-1.16 \%$ ) and from 3.35 to $3.48 \%$ o (from - 0.89 to $-1.17 \%$ ), respectively (Table 1 and Fig. 8 ). The respective averages of the $\delta^{13} \mathrm{C}$ and $\delta^{18} \mathrm{O}$ with $95 \%$ confidence levels were $3.45 \pm 0.02 \%$ and $-0.99 \pm 0.07 \%$ for KMJ-40 and KMJ-34 samples $(N=10)$ and $3.39 \pm$ $0.01 \%$ and $-1.01 \pm 0.03 \%$ for KMJ-38 samples $(N=$ 26) (Table 1). No significant difference was found between the two population averages for $\delta^{18} \mathrm{O}(0.01 \pm$ $0.08 \%$ ). The $\delta^{13} \mathrm{C}$ average for KMJ-38 samples (presumably 2014-2016) was slightly lower than that for KMJ-40 and KMJ-34 samples (presumably 2013-2015) with a significant difference of $0.06 \pm 0.03 \%$, which may reflect the Suess Effect widely accepted as a result of the burning of ${ }^{12} \mathrm{C}$-enriched fossil fuels (Keeling et al. 1979; Quay et al. 1992). The effect has decreased $\delta^{13} \mathrm{C}$ of dissolved inorganic carbon (DIC) in seawater since the mid-20th century because of the accelerated increase of anthropogenically derived $\mathrm{CO}_{2}$ with isotopically low $\delta^{13} \mathrm{C}$ values into the ocean from the atmosphere, results of which are recorded in corals and sclerosponges (e.g., Böhm et al. 2002; Asami et al. 2005; Swart et al. 2010). The difference is roughly consistent with decreasing $\delta^{13} \mathrm{C}$ rates of - 0.03\%/year for 2000-2016 (atmospheric $\mathrm{CO}_{2}$ at $\mathrm{Ha}$ waii: derived from Scripps $\mathrm{CO}_{2}$ Program initiated in 1956 by Keeling CD) and $-0.07 \%$ /year for $2000-2010$ (coral data in the Ryukyu Islands; Asami et al. unpublished data).

Cross plots of $\delta^{13} \mathrm{C}$ and $\delta^{18} \mathrm{O}$ records of our 36 sclerosponge samples converged respectively to the averages of $3.41 \%$ and $-1.00 \%$ with very slight standard deviations of $\pm 0.04 \%$ and $\pm 0.08 \%$ o (Fig. 8). The relationship between average $\delta^{13} \mathrm{C}$ and $\delta^{18} \mathrm{O}$ values of all samples yielded a very weak correlation coefficient of $0.27(p>$ 0.01 , Table 2), which is unlike those found in photosynthetic marine organisms. Therefore, one can reasonably infer that the intraspecific $\delta^{13} \mathrm{C}$ and $\delta^{18} \mathrm{O}$ variations (individual difference) for the species $A$. willeyana are quite small and hardly influenced by vital effects because the sclerosponges grow without the need for light and symbiotic algae.

\section{Elements/Ca ratios}

The average $\mathrm{Sr} / \mathrm{Ca}(\mathrm{U} / \mathrm{Ca}$ ) ratios of $A$. willeyana samples collected in October 2015 and November 2016 fell within quite narrow ranges from 9.36 to $9.76 \mathrm{mmol} / \mathrm{mol}$ (from 3.12 to $3.27 \mu \mathrm{mol} / \mathrm{mol}$ ) and from 9.15 to 9.80 $\mathrm{mmol} / \mathrm{mol}$ (from 3.11 to $3.54 \mu \mathrm{mol} / \mathrm{mol}$ ), respectively (Table 1 and Fig. 8). The respective $\mathrm{Sr} / \mathrm{Ca}$ and $\mathrm{U} / \mathrm{Ca}$ averages with $95 \%$ confidence levels were $9.50 \pm 0.08$ 

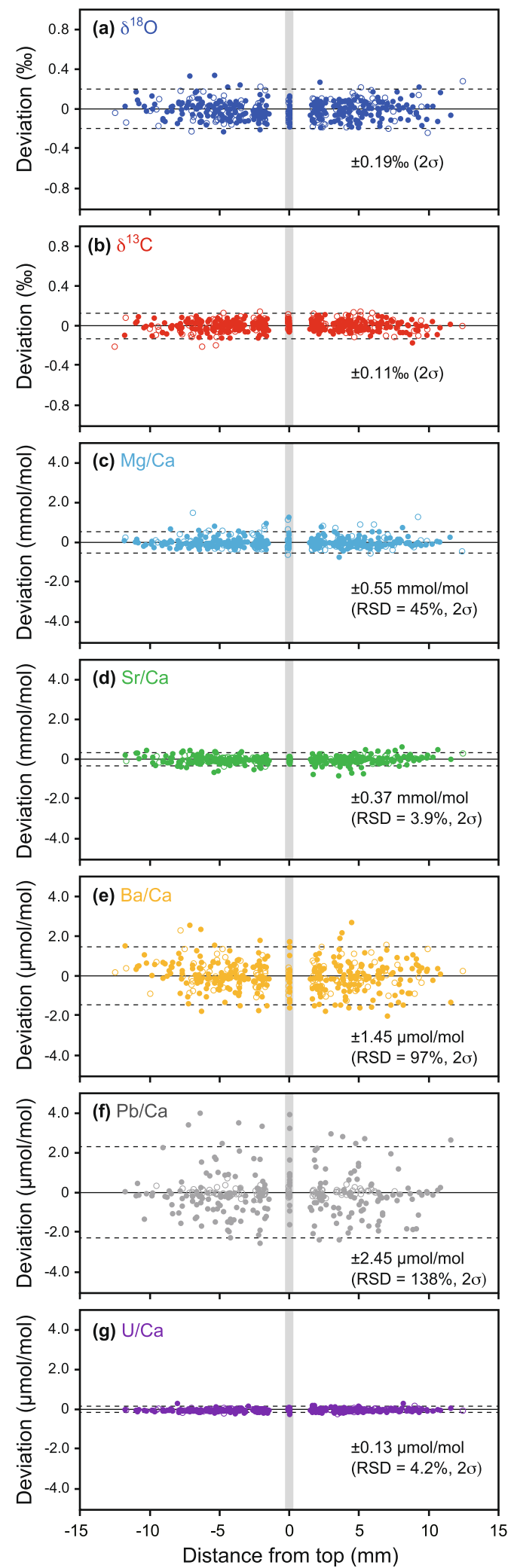

Fig. 6 Within-skeleton variations in $\mathbf{a} \delta^{18} \mathrm{O}$ and $\mathbf{b} \delta^{13} \mathrm{C}$ values and $\mathbf{c}-$ $\mathbf{g}$ elements/Ca ratios of sclerosponges. Deviations to the average in an individual sample are shown. Horizontal lines and dotted lines respectively represent zero and standard deviation (2б)

$\mathrm{mmol} / \mathrm{mol}$ and $3.21 \pm 0.03 \mu \mathrm{mol} / \mathrm{mol}$ for $\mathrm{KMJ}-40$ and KMJ-34 samples $(N=10)$ and $9.43 \pm 0.07 \mathrm{mmol} / \mathrm{mol}$ and $3.28 \pm 0.04 \mu \mathrm{mol} / \mathrm{mol}$ for KMJ-38 samples $(N=26)$ (Table 1). No significant difference was found between the two population averages for $\mathrm{Sr} / \mathrm{Ca}(0.08 \pm 0.10$ $\mathrm{mmol} / \mathrm{mol})$ and $\mathrm{U} / \mathrm{Ca}(0.07 \pm 0.05 \mu \mathrm{mol} / \mathrm{mol})$. Furthermore, the $\mathrm{Sr} / \mathrm{Ca}$ and $\mathrm{U} / \mathrm{Ca}$ records are in agreement with those of the same species from other regions in the Pacific Ocean (Table 3). Consequently, these results strongly suggest that intraspecific variations are negligibly small for $\mathrm{Sr} / \mathrm{Ca}$ and $\mathrm{U} / \mathrm{Ca}$ of $A$. willeyana.

The mean values of within-skeletal $\mathrm{Mg} / \mathrm{Ca}, \mathrm{Ba} / \mathrm{Ca}$, and $\mathrm{Pb} / \mathrm{Ca}$ ratios fall within $1.33-2.11 \mathrm{mmol} / \mathrm{mol}, 0.59$ $2.97 \mu \mathrm{mol} / \mathrm{mol}$, and $0.45-0.81 \mu \mathrm{mol} / \mathrm{mol}$ for $\mathrm{KMJ}-40$ and KMJ-34 samples (collected in 2015) and 0.86-2.14 $\mathrm{mmol} / \mathrm{mol}, \quad 0.09-2.41 \mu \mathrm{mol} / \mathrm{mol}$, and $0.08-4.55 \mu \mathrm{mol} /$ mol for KMJ-38 samples (collected in 2016), respectively (Table 1 and Fig. 8). The respective $\mathrm{Mg} / \mathrm{Ca}$ and $\mathrm{Ba} / \mathrm{Ca}$ averages with $95 \%$ confidence levels were $1.56 \pm 0.16$ $\mathrm{mmol} / \mathrm{mol}$ and $1.86 \pm 0.45 \mu \mathrm{mol} / \mathrm{mol}$ for $\mathrm{KMJ}-40$ and $\mathrm{KMJ}-34$ and $1.21 \pm 0.11 \mathrm{mmol} / \mathrm{mol}$ and $1.22 \pm$ $0.31 \mu \mathrm{mol} / \mathrm{mol}$ for KMJ-38 (Table 1). The differences between the two population averages for $\mathrm{Mg} / \mathrm{Ca}(0.35 \pm$ $0.20 \mathrm{mmol} / \mathrm{mol})$ and for $\mathrm{Ba} / \mathrm{Ca}(0.64 \pm 0.55 \mu \mathrm{mol} / \mathrm{mol})$ were statistically significant but not so large (Fig. 8). The respective $\mathrm{Pb} / \mathrm{Ca}$ averages with $95 \%$ confidence levels were $0.66 \pm 0.09 \mu \mathrm{mol} / \mathrm{mol}$ for KMJ-40 and KMJ-34 and $2.09 \pm 0.61 \mu \mathrm{mol} / \mathrm{mol}$ for $\mathrm{KMJ}-38$, the difference of which is significant $(1.42 \pm 0.62 \mu \mathrm{mol} / \mathrm{mol})$. The intraspecific variations for $\mathrm{Mg} / \mathrm{Ca}, \mathrm{Ba} / \mathrm{Ca}$, and $\mathrm{Pb} / \mathrm{Ca}$ may be due to an individual difference in biological controls on skeletal partitioning of the trace elements.

For $\mathrm{Mg} / \mathrm{Ca}$, the mechanisms of magnesium incorporation into aragonite are very complicated: loosely bound in the crystal lattice, bound to metal sites of organic compounds, and/or adsorbed onto crystal surface (Amiel et al. 1973). The intraspecific $\mathrm{Mg} / \mathrm{Ca}$ variations may be due to individual differences in organic phases and the metal binding capacity of sclerosponge tissue layers. For $\mathrm{Ba} / \mathrm{Ca}$, the mode of incorporation of barium into the sclerosponge skeleton remains unknown (e.g., Rosenheim et al. 2005b; Allison et al. 2012). Sclerosponges contain a large amount of bacteria living within their tissue (Wörheide 1998). One possibility to explain the intraspecific $\mathrm{Mg} / \mathrm{Ca}$ and $\mathrm{Ba} / \mathrm{Ca}$ variations found in this study is that the physiological processes associated with these bacteria may have an effect on the incorporation of $\mathrm{Mg}^{2+}$ and $\mathrm{Ba}^{2+}$ for calcification at a micro-environmental level (Rosenheim et al. 2005b). Further, the intraspecific variation indicates that 


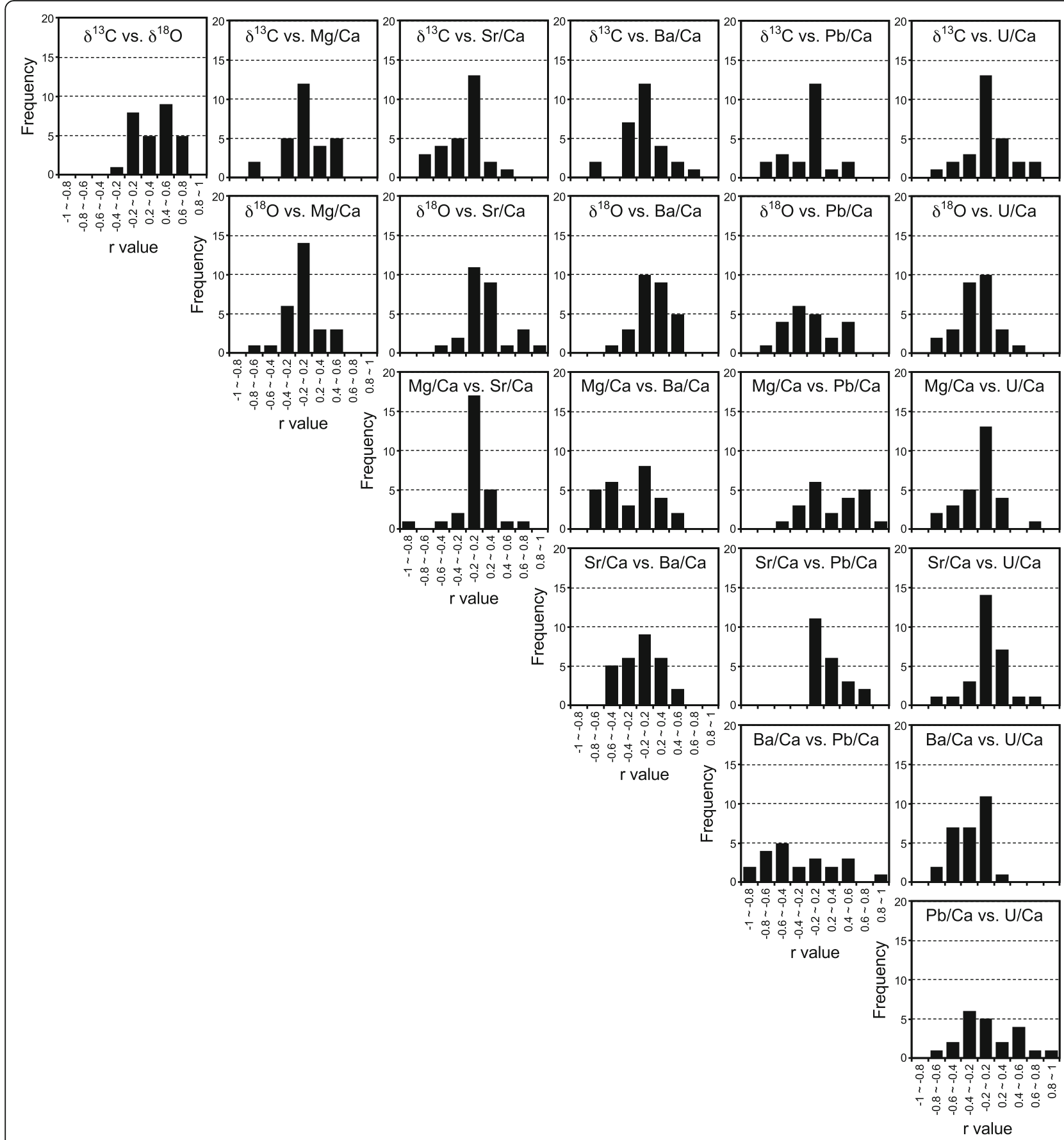

Fig. 7 Frequency distributions (histograms) of correlation coefficients among geochemical records of sclerosponges. The $Y$-axis represents the number of individuals (sample number: $N$ ). The $r$ values are divided into nine classes in the $X$-axis. A trend of the respective relations of two within-skeleton geochemical components is visualized. High frequency with $r$ values of $-0.4-0.4$ indicates a little significant relationship in within-skeletal geochemistry

the efficiency for transporting elements into the calcification site may be different among individuals because of the large discrepancy in the cationic radii of $\mathrm{Mg}^{2+}$ and $\mathrm{Ba}^{2+}$ relative to $\mathrm{Ca}^{2+}$ unlike $\mathrm{Sr}^{2+}$ (Gaetani and Cohen 2006).

$\mathrm{The} \mathrm{Pb} / \mathrm{Ca}$ profiles along a growth direction shows historical changes associated with environmental lead pollution (e.g., Lazareth et al. 2000; Swart et al. 2002; Ohmori et al. 2014). Skeletal $\mathrm{Pb} / \mathrm{Ca}$ in a Acanthochaetetes wellsi (high-Mg calcite) collected from the same locality as our study (Kume Island, Japan) varied roughly from 200 to $1000 \mathrm{nmol} / \mathrm{mol}$ for $2000-2007$ (Ohmori et al. 2014) and that in a Ceratoporella nicholsoni (aragonite) from the 

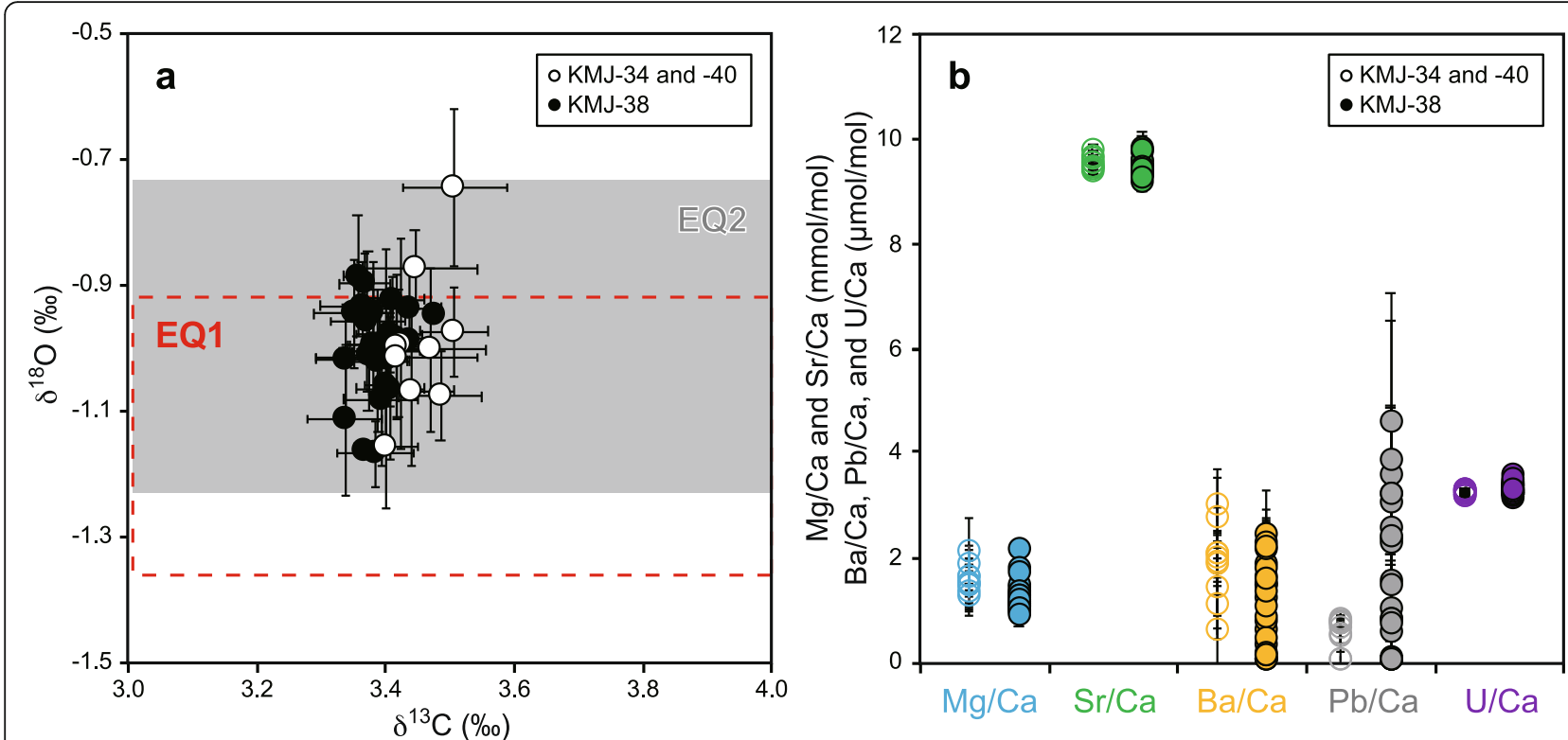

Fig. 8 Scatter plot of $\mathbf{a} \delta^{18} \mathrm{O}$ and $\delta^{13} \mathrm{C}$ and $\mathbf{b}$ elements/Ca ratios of sclerosponges. Data are shown as averages with $1 \sigma$ standard deviations in individual samples, which show intraspecific variations in sclerosponge geochemistry. Red (EQ1) and gray (EQ2) areas are shown respectively as estimated ranges of isotopically equilibrium aragonite precipitated at the study site using a relation between seawater $\delta^{18} \mathrm{O}$ and salinity by Oba (1990) and Abe et al. (2009)

Caribbean Sea varied roughly from 90 to $120 \mathrm{nmol} / \mathrm{mol}$ for 1999-2001 (Rosenheim et al. 2005b). Considering the $\mathrm{Pb} / \mathrm{Ca}$ averages of our samples $(1648 \pm 421 \mathrm{nmol} / \mathrm{mol})$, interspecific variations are large. Sclerosponges incorporate $\sim 10$ times higher $\mathrm{Pb}$ than corals because pumping and filtering particulates, which absorb heavy metal species, are the only source of nutrition for sclerosponges (e.g., Hartman and Goreau 1966; Willenz and Hartman 1989). Therefore, it is inferred that the amounts, size, and/or species of filtered particles may be considerably different among individuals and species.

Differences in the geochemistry among micro-scale skeletal structures may reflect variations in the composition of the precipitation fluid, the incorporation of ions into the skeleton, and/or kinetic effects (Gabitov et al. 2008). In most cases, apparent relationships among elements/Ca and isotope data of all samples were not founded, yielding a very weak correlation coefficient ranging from -0.38 to 0.29 (Table 2). This may indicate that the millimeter scale analyses carried out in this study smoothed the heterogeneity of skeletal geochemistry, which results in a smoothing of environmental signals to no small extent through the living tissue layer. Meanwhile, there significantly exist weak correlations between $\mathrm{Sr} / \mathrm{Ca}$ and $\delta^{18} \mathrm{O}(r=0.47), \mathrm{Mg} / \mathrm{Ca}$ and $\mathrm{Pb} / \mathrm{Ca}(r=-0.56)$, and $\mathrm{Ba} / \mathrm{Ca}$ and $\mathrm{U} / \mathrm{Ca}(r=-0.69)$, but their relationships can explain only $22-48 \%$ in the respective variance. The former may reflect a difference in skeletal growth rate among the individual samples because both sclerosponge $\mathrm{Sr} / \mathrm{Ca}$ and $\delta^{18} \mathrm{O}$ strongly correlated negatively with seawater temperature. At this point, no clear reason underlying the latter two can be inferred. However, the negative relation between $\mathrm{Mg} / \mathrm{Ca}$ and $\mathrm{Pb} / \mathrm{Ca}$ found in this study can be explained by an indication that sclerosponges would acquire more $\mathrm{Mg}^{2+}$ nutritionally with a decrease in pumping of ambient water and particulates with adsorbed $\mathrm{Pb}$ species (Willenz and Hartman 1989; Rosenheim et al. 2005b). The significant negative correlation of the comparatively high $r$ value of -0.69 between $\mathrm{Ba} / \mathrm{Ca}$ and $\mathrm{U} / \mathrm{Ca}$ in

Table 2 Correlations between average values of sclerosponge geochemistry*

\begin{tabular}{|c|c|c|c|c|c|c|}
\hline & $\delta^{18} \mathrm{O}$ & $\mathrm{Mg} / \mathrm{Ca}$ & $\mathrm{Sr} / \mathrm{Ca}$ & $\mathrm{Ba} / \mathrm{Ca}$ & $\mathrm{Pb} / \mathrm{Ca}$ & $\mathrm{U} / \mathrm{Ca}$ \\
\hline$\overline{\delta^{13} \mathrm{C}}$ & 0.27 & 0.22 & 0.17 & 0.22 & -0.35 & -0.11 \\
\hline$\delta^{18} \mathrm{O}$ & & -0.06 & 0.47 & 0.29 & -0.04 & -0.06 \\
\hline $\mathrm{Mg} / \mathrm{Ca}$ & & & -0.11 & 0.18 & -0.56 & 0.02 \\
\hline $\mathrm{Sr} / \mathrm{Ca}$ & & & & 0.16 & -0.01 & -0.12 \\
\hline $\mathrm{Ba} / \mathrm{Ca}$ & & & & & -0.38 & -0.69 \\
\hline $\mathrm{Pb} / \mathrm{Ca}$ & & & & & & 0.19 \\
\hline
\end{tabular}

"Coefficent values in italics and bold fall outside $(p>0.01)$ and inside $(p<0.01)$ the $99 \%$ confidence intervals, respectively 
Table 3 Average elemental ratios and partition coefficients for aragonite sclerosponges

\begin{tabular}{|c|c|c|c|c|c|c|c|c|}
\hline & Species & Site & $\begin{array}{l}\text { Depth } \\
\text { (m) }\end{array}$ & $\begin{array}{l}\mathrm{Mg} / \mathrm{Ca}(\mathrm{mmol} / \\
\mathrm{mol})\end{array}$ & $\begin{array}{l}\mathrm{Sr} / \mathrm{Ca}(\mathrm{mmol} / \\
\mathrm{mol})\end{array}$ & $\begin{array}{l}\mathrm{Ba} / \mathrm{Ca}(\mu \mathrm{mol} / \\
\mathrm{mol})\end{array}$ & $\begin{array}{l}\mathrm{Pb} / \mathrm{Ca}(\mathrm{nmol} / \\
\mathrm{mol})\end{array}$ & $\begin{array}{l}\mathrm{U} / \mathrm{Ca}(\mu \mathrm{mol} / \\
\mathrm{mol})\end{array}$ \\
\hline \multicolumn{9}{|l|}{ This study } \\
\hline Avg. $(95 \% \mathrm{CL})$ & \multirow{2}{*}{$\begin{array}{l}\text { A. } \\
\text { willeyana }\end{array}$} & \multirow[t]{2}{*}{ Kume Is., Japan } & \multirow[t]{2}{*}{$30-40$} & $1.31 \pm 0.11$ & $9.45 \pm 0.05$ & $1.42 \pm 0.26$ & \multirow[t]{2}{*}{$1648 \pm 421$} & $3.26 \pm 0.03$ \\
\hline$D_{M e, \text { Arag }}$ & & & & $3.62-4.27 \times 10^{-4}$ & $1.09-1.11$ & $0.007-0.017$ & & $2.28-2.35$ \\
\hline \multicolumn{9}{|c|}{ Rosenheim et al. (2005) } \\
\hline Avg. $( \pm 1 \sigma)$ & \multirow{2}{*}{$\begin{array}{l}\text { C. } \\
\text { nicholsoni }\end{array}$} & \multirow[t]{2}{*}{ Jamaica } & \multirow[t]{2}{*}{22} & $0.85-0.92$ & $9.45-9.89$ & $3.60-4.14$ & \multirow[t]{2}{*}{ 8.13-91.9 } & \multirow[t]{2}{*}{$3.20-3.37$} \\
\hline$D_{M e, \text { Arag }}$ & & & & $1.81 \times 10^{-4}$ & 1.10 & 0.098 & & \\
\hline Average $( \pm 1 \sigma)$ & \multirow{2}{*}{$\begin{array}{l}\text { C. } \\
\text { nicholsoni }\end{array}$} & \multirow[t]{2}{*}{ Bahamas } & \multirow[t]{2}{*}{143} & $0.77-0.90$ & $10.15-10.74$ & $3.16-3.66$ & $52.10-289$ & $3.07-3.28$ \\
\hline$D_{M e, \text { Arag }}$ & & & & $1.6 \times 10^{-4}$ & 1.17 & 0.86 & 171.85 & 2.98 \\
\hline \multicolumn{9}{|l|}{ Fallon et al. (2005) } \\
\hline Avg. (1980-1994) & $\begin{array}{l}\text { A. } \\
\text { willeyana }\end{array}$ & $\begin{array}{l}\text { Otta Island, } \\
\text { Micronesia }\end{array}$ & 25 & $0.9-1.2$ & $9.5-12.0$ & $2.7-4.1$ & & $3.1-3.6$ \\
\hline \multicolumn{9}{|l|}{ Allison et al. (2012) } \\
\hline $\begin{array}{l}\text { Avg. (-2004, several } \\
\text { yrs) }\end{array}$ & $\begin{array}{l}\text { A. } \\
\text { willeyana }\end{array}$ & $\begin{array}{l}\text { Nomuka lka, } \\
\text { Tonga }\end{array}$ & 9.5 & $0.3-1.1$ & $8.5-12.5$ & $2.5-8.0$ & & \\
\hline
\end{tabular}

our sclerosponge samples possibly reflects a significant positive relation between $\mathrm{Ba} / \mathrm{Ca}$ and sample size (a parameter presumably related to biological and skeletal growth rate) (Fig. 9) and the significant negative relationship between $\mathrm{U} / \mathrm{Ca}$ and seawater carbonate ion concentration (relating to $\mathrm{pH}$ and aragonite saturation degree) for deep-sea azooxanthellate corals (Anagnostou et al. 2011).

\section{Compared with equilibrium aragonite for stable isotopes}

To evaluate the fidelity of $A$. willeyana as a paleoenvironmental proxy, we compared our data with the $\delta^{13} \mathrm{C}$ and $\delta^{18} \mathrm{O}$ values of aragonites that are inorganically precipitated in isotopic equilibrium with seawater at the sclerosponge growth site: "equilibrium aragonite."
The $\delta^{18} \mathrm{O}$ values were calculated using an equation $\left(1000 \times \ln \alpha=17.88\left(10^{3} / T\right)-31.14\right)$ derived from laboratory synthesis experiments of aragonite at water temperatures of $0-40{ }^{\circ} \mathrm{C}$ (Kim et al. 2007). Therein, $\alpha$ is the fractionation factor between aragonite and water; $T$ is in degrees Kelvin. Although showing good consistency with the climatological data products (Fig. 2), the in situ observational data of this study (October 2015 to November 2016) are temporally limited relative to the growth periods (a few years) of investigated skeletal portions. Based on skeletal growth characteristics for $A$. willeyana reported from earlier works (see the "Materials and methods" section), for this study, the investigated skeletal increments of our sclerosponges were
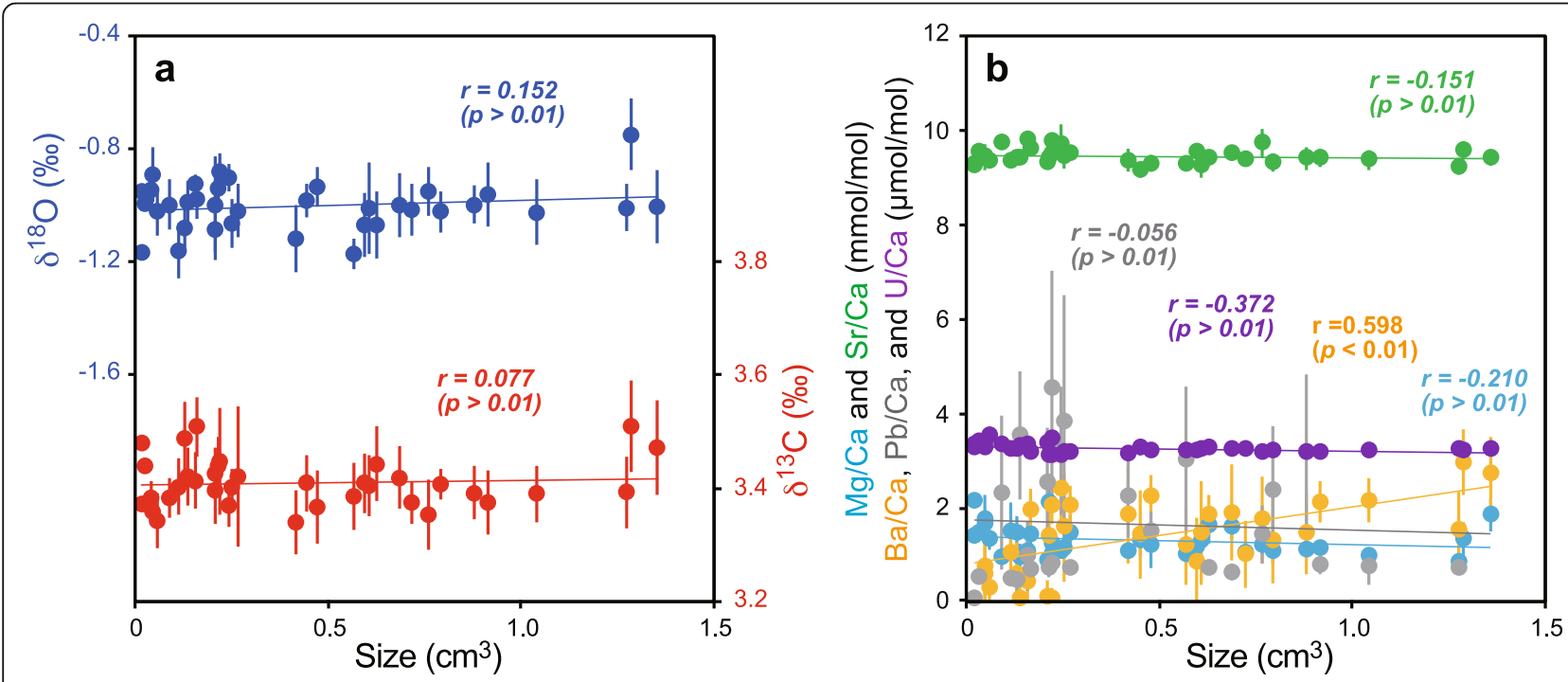

Fig. 9 Relationship between sample size and $\mathbf{a} \delta^{18} \mathrm{O}$ and $\delta^{13} \mathrm{C}$ and $\mathbf{b}$ elements/Ca ratios of sclerosponges 
assumed to be precipitated for 2013-2016. Consequently, the annual mean seawater temperature $\left(25.4^{\circ} \mathrm{C}\right)$ and the variation $\left( \pm 0.9^{\circ} \mathrm{C}, 2 \sigma\right)$ for $2013-2016$ were estimated from JODC and Integrated Global Ocean Services System gridded data $\left(26^{\circ}-27^{\circ} \mathrm{N}, 126^{\circ}-127^{\circ} \mathrm{E}\right.$ : Reynolds et al. 2002). The seawater $\delta^{18} \mathrm{O}$ values of $0.26 \pm 0.05 \%$ or $0.43 \pm 0.08 \%$ were estimated respectively from JODC salinity data using a relation for the East China Sea Kuroshio Current region (Oba 1990) (case 1) or for Ishigaki Island in the southern Ryukyus (Abe et al. 2009) (case 2). These estimations are consistent with $\delta^{18} \mathrm{O}$ values $(0.18 \%$ in November $2009,0.25-0.29 \%$ in October 2015, 0.35\% in March 2016) of seawater samples collected at water depths of $34-40 \mathrm{~m}$ in this study area. Consequently, the $\delta^{18} \mathrm{O}$ values of equilibrium aragonites precipitated at the study site for 2013-2016 are expected to fall within a range of $-0.92 \%$ to $-1.37 \%$ (case 1 : shown as EQ1 in Fig. 8) or from - 0.73\% to - $1.23 \%$ (case 2: shown as EQ2 in Fig. 8) at 95\% confidence intervals.

The $\delta^{13} \mathrm{C}$ values of the equilibrium aragonites were estimated using DIC $\delta^{13} \mathrm{C}$ of seawater, the carbon-isotope fractionation factors among $\mathrm{CO}_{2}$ species (Zhang et al. 1995), and the aragonite- $-\mathrm{HCO}_{3}-$ enrichment factor $(2.7$ \pm 0.6\%; Romanek et al. 1992). Because of the lack of data on DIC $\delta^{13} \mathrm{C}$ of seawater around the study site, the annual $\delta^{13} \mathrm{C}$ value of DIC at a water depth of $40 \mathrm{~m}$ is assumed to be the medium value $(0.68 \%$ ) between November and August estimated using two significant relations established west of Okinawa Island $\left(r^{2}=0.810\right.$; Takayanagi et al. 2012) and southeast of Okinawa Island $\left(r^{2}=\right.$ 0.997; Suzuki et al. 2009). Consequently, the $\delta^{13} \mathrm{C}$ values of the equilibrium aragonites are expected to be roughly $3.0-4.2 \%$ (Fig. 8). It is noteworthy that the estimated $\delta^{13} \mathrm{C}$ values are approximate because of the limitations and uncertainty of the dataset.

The skeletal $\delta^{13} \mathrm{C}$ and $\delta^{18} \mathrm{O}$ values in our 36 sclerosponge samples almost fell within the probable ranges (case 1 and case 2) of the equilibrium aragonites precipitated at the living site (Fig. 8). This result strongly shows that the $\delta^{13} \mathrm{C}$ and $\delta^{18} \mathrm{O}$ of $A$. willeyana is not be influenced isotopically by vital physiological effects. Furthermore, no strong correlation exists between the isotope composition and the sclerosponge sample size $(r=0.076$ for $\delta^{13} \mathrm{C}$ and $r=0.150$ for $\delta^{18} \mathrm{O}, p>0.01$ ) (Fig. 9), unlike symbiont corals for which the isotopic variations (the degree of disequilibrium) are related to the skeletal growth rate (e.g., McConnaughey 1989; Felis et al. 2003). $\delta^{13} \mathrm{C}$ and $\delta^{18} \mathrm{O}$ values of corals with symbiotic algae are well known to differ greatly from those of equilibrium aragonite because of kinetic and metabolic fractionation effects (e.g., Aharon 1991; McConnaughey 2003). We therefore suggest that the fractionation effects have little influence on the isotopic composition of $A$. willeyana because the skeletal growth is expected to constant at a very slow rate. Our results are supported strongly by evidence from earlier studies showing that $\delta^{18} \mathrm{O}$ values of living sclerosponges (seven C. nicholsoni from the Caribbean Sea and a A. willeyana from the Great Barrier Reef) are in good agreement with published values from synthetic aragonite and near-equilibrium values of mollusks and foraminifers (Böhm et al. 2000) and that sclerosponges (three $C$. nicholsoni from the Caribbean Sea and a $A$. wellsi from New Caledonia) precipitate $\mathrm{CaCO}_{3}$ skeletons close to isotopic equilibrium for $\delta^{13} \mathrm{C}$ values (Böhm et al. 1996).

\section{Partition coefficients of elements/Ca}

Partition coefficients, apparent distribution coefficients $\left(D_{M e}\right.$, Arag $)$, were estimated using element/Ca ratios between seawater and aragonitic skeleton of sclerosponge, except for $\mathrm{Pb} / \mathrm{Ca}$ (Table 3). As it is known that the $D_{S r}$, Arag of inorganic aragonite depends on water temperature (e.g., Kinsman and Holland 1969; DeCarlo et al. 2015), sclerosponge $\mathrm{Sr} / \mathrm{Ca}$ can be useful for a proxy of seawater temperature (e.g., Rosenheim et al. 2004; Haase-Schramm et al. 2005; Waite et al. 2018). The $D_{S r}$, Arag from our $A$. willeyana samples was 1.09-1.11 (almost unity), which is consistent with that of $C$. nicholsoni from the Caribbean Sea (Rosenheim et al. 2005b) (Table 3) and experimentally precipitated abiogenic aragonite (Gaetani and Cohen 2006; DeCarlo et al. 2015). The average $\mathrm{Sr} / \mathrm{Ca}$ of $~ 9.5$ $\mathrm{mmol} / \mathrm{mol}$ in our sclerosponges was identical to an estimation of inorganic aragonite of $9.42-9.50 \mathrm{mmol} / \mathrm{mol}$ at $25.4 \pm 0.9^{\circ} \mathrm{C}$ calculated by using the experimentally established relationship (Gaetani and Cohen 2006) and almost consistent with previously reported values for the same species in the Pacific Ocean (Fallon et al. 2005; Grottoli et al. 2010; Allison et al. 2012). Furthermore, highresolution $\mathrm{Sr} / \mathrm{Ca}$ records of aragonitic skeleton for A. willeyana (Fallon et al. 2005) and C. nicholsoni (Rosenheim et al. 2004) using LA-ICP-MS have been shown to be seasonal variations, yielding significant calibrations for seawater temperature. Therefore, these lines of evidence suggest that $A$. willeyana sclerosponge $\mathrm{Sr} / \mathrm{Ca}$ can be a robust indicator of seawater temperature.

The value of $D_{M g}$, Arag estimated from our samples shows that $A$. willeyana sclerosponge $\mathrm{Mg} / \mathrm{Ca}$ ratios are several orders $\left(10^{-3}\right.$ to $\left.10^{-4}\right)$ of magnitude smaller than those of seawater (Table 3). The value is about twice that of the species C. nicholsoni (Rosenheim et al. 2005b), but about one order of magnitude less than experimentally precipitated inorganic aragonite (Gaetani and Cohen 2006). The $D_{B a \text {, Arag }}$ estimated from our samples shows that $\mathrm{Ba} / \mathrm{Ca}$ ratios in A. willeyana sclerosponge are variable and about two orders of magnitude less than those of seawater. The $D_{B a, A r a g}$ value estimated in this study is about several orders $\left(10^{-1}\right.$ to $\left.10^{-2}\right)$ of 
magnitude less than those for the species C. nicholsoni (Rosenheim et al. 2005b) and inorganic aragonite (Gaetani and Cohen 2006; Mavromatis et al. 2018). Rosenheim et al. (2005b) also reported that C. nicholsoni sclerosponges showed large variations in their $D_{B a}$, Arag values of about 0.1-0.9 (Table 3). Such a small $D_{B a}$, Arag value of $<1$ for sclerosponge samples can be reasonably explained by the lower incorporation of an incompatible trace metal because of the large difference of $\sim 25 \%$ in ionic radius between $\mathrm{Ba}^{2+}$ and $\mathrm{Ca}^{2+}$, as was true also for other aragonite materials such as synthetic aragonite (Mavromatis et al. 2018), speleothems (e.g., Wassenburg et al. 2016), bivalves (e.g., Poulain et al. 2015), and fish otoliths (e.g., Bath et al. 2000) in contrast to corals, which were greater than unity (e.g., Gonneea et al. 2017). However, such a different value of $\sim 0.01$ to $\sim 0.9$ (Table 3) indicates that physiological processes for the incorporation of $\mathrm{Ba}^{2+}$ into aragonitic sclerosponges for calcification differ greatly not only among individuals but also among species. Perhaps for this reason, significant correlations exist between the $\mathrm{Ba} / \mathrm{Ca}$ and the sclerosponge sample size found in this study $(r=\sim 0.6, p<$ 0.01) (Fig. 9). Furthermore, results of a study of element partitioning during aragonite precipitation suggest that the calcifying fluid from which coral skeleton precipitates is depleted in $\mathrm{Mg}$ and $\mathrm{Ba}$, unlike $\mathrm{Sr}$. Results also suggest that seasonal fluctuations exist in the mass fraction of aragonite precipitated from the fluid (precipitation efficiency) (Gaetani and Cohen 2006), which can qualitatively explain our results showing lower $D_{M g}$ Arag and $D_{B a}$, Arag values and a value of $D_{S r}$, Arag that is almost equal to unity for $A$. willeyana sclerosponge. Quantitative verification of these results requires additional experimental work.

For $\mathrm{U} / \mathrm{Ca}$, the average value $(\sim 3.3 \mu \mathrm{mol} / \mathrm{mol})$ of our A. willeyana sclerosponges was consistent with those of the same species (Fallon et al. 2005) and with C. nicholsoni (Rosenheim et al. 2005b) (Table 3). The value of $D_{U \text {, Arag }}(2.3-2.4)$ estimated in this study was slightly lower than that (2.98) reported for C. nicholsoni (Rosenheim et al. 2005b) and much higher than the experimentally determined value $(0.31 \pm 0.06)$ of inorganic aragonite precipitation at $25.5^{\circ} \mathrm{C}$ (DeCarlo et al. 2015). Degradation of tissue layers and/or bacteria can influence the $\mathrm{pH}$ and carbonate species system of the calcifying fluid, thereby altering the $\mathrm{U} / \mathrm{Ca}$ ratios in sclerosponge skeleton at different levels, which possibly caused differences in $\mathrm{U} / \mathrm{Ca}$ among sclerosponge species. Although coralline aragonite U/Ca records are apparently correlated with temperature (e.g., Min et al. 1995; Shen and Dunbar 1995), several recent studies demonstrated that the U/Ca ratios of azooxanthellate deep sea coral (Anagnostou et al. 2011) and experimentally precipitated aragonite from seawater (DeCarlo et al. 2015) have significant negative correlation with carbonate ion concentrations because the aqueous chemistry of uranium is influenced by the carbonate ion, which forms complexes with the uranyl ion (Langmuir 1978). The sclerosponge $\mathrm{U} / \mathrm{Ca}$ is about $2-3$ times higher than that of zooxanthellate corals, which may be related to lowering of $\mathrm{pH}$ and carbonate ion concentrations in the calcifying fluid. These lines of implication might bring higher

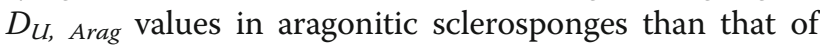
synthetic aragonite. Although the complicated mechanism for the incorporation of uranyl complexes into calcium carbonate has not been resolved, the slight intraspecific variations $( \pm 0.03 \mu \mathrm{mol} / \mathrm{mol}$, the relative variation is $0.9 \%)$ of sclerosponge $\mathrm{U} / \mathrm{Ca}$ for the A. willeyana species examined in this study (Fig. 8) support the possibility of its use as a proxy for ocean environments.

\section{Conclusions}

Results of this study are important scientific findings for the hypercalcified demosponge Astrosclera willeyana; (1) within-skeletal variation is quite small for $\delta^{13} \mathrm{C}, \delta^{18} \mathrm{O}$, $\mathrm{Sr} / \mathrm{Ca}$, and $\mathrm{U} / \mathrm{Ca}$ (namely, little heterogeneity in the coevally precipitated skeleton); (2) intraspecific variations are quite small for $\delta^{13} \mathrm{C}, \delta^{18} \mathrm{O}, \mathrm{Sr} / \mathrm{Ca}$, and $\mathrm{U} / \mathrm{Ca}$ (namely, little individual difference); (3) the aragonite skeleton is precipitated in or very close to isotopic equilibrium with seawater at the living site; (4) the isotopic composition of the skeleton is scarcely affected by kinetic and biological effects; (5) the partition coefficient of $\mathrm{Sr} / \mathrm{Ca}$ is consistent with that for different species and close to inorganic aragonite.

We believe that sclerosponge $\mathrm{U} / \mathrm{Ca}$ may be a paleoenvironmental proxy although there are still unknowns relating to uranium into the aragonitic skeleton. Relatively large variations and individual differences in the sclerosponge $\mathrm{Mg} / \mathrm{Ca}, \mathrm{Ba} / \mathrm{Ca}$, and $\mathrm{Pb} / \mathrm{Ca}$ were shown in this study. To clarify the reasons for controlling factors of incorporation (distribution) of the elements into the sclerosponge aragonite skeleton, further investigations such as ultra-high resolution analyses and culture experiments are needed. Importantly, we suggest that $A$. willeyana $\delta^{18} \mathrm{O}\left(\delta^{13} \mathrm{C}\right)$ is very suitable as an environmental proxy to reconstruct seawater temperature and $\delta^{18} \mathrm{O}$ (DIC $\delta^{13} \mathrm{C}$ ) for the past. Coupled determination of $\mathrm{Sr} / \mathrm{Ca}$ and $\delta^{18} \mathrm{O}$ in a sclerosponge can potentially enable the construction of independent time series for both seawater temperature and $\delta^{18} \mathrm{O}(\fallingdotseq$ salinity $)$ at near-annual resolution by using a millimeter-scale sampling protocol for widely used and convenient methods. Furthermore, in combination with the geochemistry of marine calcified organisms living in shallow waters, such as corals and giant clams, long-lived sclerosponge-based reconstruction of deeper ocean environments can generate a long time series of spatial and vertical changes in coral 
reef environments for the past few hundred years, extending beyond the observation data. This study also presents the important implication that even if only a few skeletal fragments and a few sclerosponge samples are collected, one can reconstruct annual average paleoceanographic conditions using well-preserved fossils that have not been altered diagenetically. Regarded from these viewpoints, our results can support contributions toward broad applications not only to climatology and oceanography but also to geology and biogeochemistry.

\section{Abbreviations}

JODC: Japan Oceanographic Data Center; VPDB: Vienna Standard Pee Dee Belemnite; VSMOW: Vienna Standard Mean Ocean Water

\section{Acknowledgements}

We are grateful to a chief editor (Prof. H. Kawahata) and two anonymous reviewers for their helpful and valuable suggestions and comments on the manuscript. We also thank M. Kondo (Okinawa Institute of Science and Underwater Technology) for help with field surveys and Dr. H. Fujimura, M. Chinen, and Y. Akamine (University of the Ryukyus) for help with experiments.

\section{Authors' contributions}

RA designed the study, analyzed the samples and data, and wrote the manuscript. TN, MM, YI, YF, and TS collaborated with RA in the fieldwork and sampling. AK, DO, RU, and RS collaborated with RA in the chemical analyses. The authors read and approved the manuscript.

\section{Funding}

This research was supported by the Japan Society for the Promotion of Science KAKENHI (Grant-in-Aid for Scientific Research) Grant numbers 26550012, 26707028, and 18K18522 to RA and 15H01729 to RU, and the NEXT Program Grant Number GR083 to TS.

\section{Availability of data and materials}

Please contact the corresponding author for data requests.

\section{Competing interests}

The authors declare that they have no competing interests.

\section{Author details}

${ }^{1}$ Institute of Geology and Paleontology, Graduate School of Science, Tohoku University, Aobayama, Sendai 980-8578, Japan. ${ }^{2}$ Department of Earth Science, Faculty of Science, University of the Ryukyus, 1 Senbaru, Nishihara, Okinawa 903-0213, Japan. ${ }^{3}$ Tropical Biosphere Research Center, Iriomote Station, University of the Ryukyus, 870 Uehara, Taketomi, Okinawa 907-1541, Japan. ${ }^{4}$ Department of Chemistry, Biology, and Marine Science, Faculty of Science, University of the Ryukyus, 1 Senbaru, Nishihara, Okinawa 903-0213, Japan. ${ }^{5}$ Division of Earth and Environmental Sciences, Graduate School of Environmental Studies, Nagoya University, Furo-cho, Chikusa-ku, Nagoya 464-8601, Japan. ${ }^{6}$ Centre for Marine and Coastal Studies (CEMACS), Universiti Sains Malaysia, 11800 USM, Penang, Malaysia. ${ }^{7}$ Okinawa Prefectural University of Arts, 1-4 Shuri-Tounokura, Naha, Okinawa 903-8602, Japan. ${ }^{8}$ Department of Civil and Environmental Engineering, Graduate School of Engineering, Tohoku University, 6-6-06 Aramaki-Aza-Aoba, Sendai 980-8579, Japan.

Received: 26 November 2019 Accepted: 15 April 2020

Published online: 12 May 2020

\section{References}

Abe O, Agata S, Morimoto M, Abe M, Yoshimura K, Hiyama T, Yoshida N (2009) A 6.5-year continuous record of sea surface salinity and seawater isotopic composition at Harbour of Ishigaki Island, southwest Japan. Isot Environ Health Stud 45:247-258. https://doi.org/10.1080/10256010903083847

Abram NJ, HV MG, Tierney JE, Evans MN, NP MK, Kaufman DS, the PAGES $2 \mathrm{k}$ Consortium (2016) Early onset of industrial-era warming across the oceans and continents. Nature 536:411-418. https://doi.org/10.1038/nature19082
Aharon P (1991) Recorders of reef environment histories: stable isotopes in corals, giant clams, and calcareous algae. Coral Reefs 10:71-90 https://doi.org/10. 1007/BF00571826

Allison N, Tudhope AW, EIMF (2012) The skeletal geochemistry of the sclerosponge Astrosclera willeyana: implications for biomineralisation processes and paleoenvironmental reconstruction. Palaeogeogr Palaeoclimatol Palaeoecol 313-314:70-77. https://doi.org/10.1016/j.palaeo. 2011.10.009

Amiel AJ, Friedman GM, Miller DS (1973) Distribution and nature of incorporation of trace elements in modern aragonitic corals. Sedimentology 20:47-64 https://doi.org/10.1111/j.1365-3091.1973.tb01606.x

Anagnostou E, Sherrell RM, Gagnon A, LaVigne M, Field MP, McDonough WF (2011) Seawater nutrient and carbonate ion concentrations recorded as P/Ca, $\mathrm{Ba} / \mathrm{Ca}$, and U/Ca in the deep-sea coral Desmophyllum dianthus. Geochim Cosmochim Acta 75:2529-2543. https://doi.org/10.1016/j.gca.2011.02.019

Asami R, Felis T, Deschamps P, Hanawa K, Iryu Y, Bard E, Durand N, Murayama M (2009) Evidence for tropical South Pacific climate change during the Younger Dryas and the Bølling-Allerød from geochemical records of fossil Tahiti corals. Earth Planet Sci Lett 288:96-107. https://doi.org/10.1016/j.epsl.2009.09.011

Asami R, Iryu Y, Hanawa K, Miwa T, Holden P, Shinjo R, Paulay G (2013) MIS 7 interglacial sea-surface temperature and salinity reconstruction from a southwestern subtropical Pacific coral. Quat Res 80:575-585 https://doi.org/ 10.1016/j.yqres.2013.09.002

Asami R, Konishi M, Tanaka K, Uemura R, Furukawa M, Shinjo R (2015) Late Holocene coral reef environment recorded in Tridacnidae shells from archaeological sites in Okinawa-jima, subtropical southwestern Japan. Island Arc 24:61-72. https://doi.org/10.1111/iar.12076

Asami R, Yamada T, Iryu Y, Quinn TM, Meyer CP, Paulay G (2005) Interannual and decadal variability of the western Pacific sea surface condition for the years 1787-2000: reconstruction based on stable isotope record from a Guam coral. J Geophys Res 110:C05018. https://doi.org/10.1029/2004JC002555

Ayling A (1982) Redescription of Astrosclera willeyana Lister 1900 (Ceratoporellida, Demospongiae), a new record from the Great Barrier Reef. Mem Nat Mus Victoria 43:99-103 https://doi.org/10.24199/j.mmv.1982.43.06

Bath GE, Thorrold SR, Jones CM, Campana SE, McLaren JW, Lam JWH (2000) Strontium and barium uptake in aragonitic otoliths of marine fish. Geochim Cosmochim Acta 64:1705-1714 https://doi.org/10.1016/S0016-7037(99)00419-6

Benavides LM, Druffel ERM (1986) Sclerosponge growth rate as determined by ${ }^{210} \mathrm{Pd}$ and $\Delta^{14} \mathrm{C}$ chronologies. Coral Reefs 4:221-224. https://doi.org/10.1007/ BF00298080

Böhm F, Haase-Schramm A, Eisenhauer A, Dullo W-C, Joachimski MM, Lehnert H, Reitner J (2002) Evidence for preindustrial variations in the marine surface water carbonate system from coralline sponges. Geochem Geophys Geosyst 3:1019. https://doi.org/10.1029/2001GC000264

Böhm F, Joachimski MM, Dullo W-C, Eisenhauer A, Lehnert H, Reitner J, Wörheide $\mathrm{G}$ (2000) Oxygen isotope fractionation in marine aragonite of coralline sponges. Geochim Cosmochim Acta 64:1695-1703. https://doi.org/10.1016/ S0016-7037(99)00408-1

Böhm F, Joachimski MM, Lehnert H, Morgenroth G, Kretschmer W, Vacelet J, Dullo W-C (1996) Carbon isotope records from extant Caribbean and South Pacific sponges: evolution of $\delta^{13} \mathrm{C}$ in surface water DIC. Earth Planet Sci Lett 139:291-303. https://doi.org/10.1016/0012-821X(96)00006-4

DeCarlo TM, Gaetani GA, Holcomb M, Cohen AL (2015) Experimental determination of factors controlling U/Ca of aragonite precipitated from seawater: implications for interpreting coral skeleton. Geochim Cosmochim Acta 162:151-165 https://doi.org/10.1016/j.gca.2015.04.016

Druffel ERM, Benavides LM (1986) Input of excess $\mathrm{CO}_{2}$ to the surface ocean based on ${ }^{13} \mathrm{C} /{ }^{12} \mathrm{C}$ ratios in a banded Jamaican sclerosponge. Nature 321:5861. https://doi.org/10.1038/321058a0

Fallon SJ, Guilderson TP (2005) Extracting growth rates from the nonlaminated coralline sponge Astrosclera willeyana using bomb radiocarbon. Limnol Oceanogr Methods 3:455-461 https://doi.org/10.4319/lom.2005.3.455

Fallon SJ, Guilderson TP, Caldeira K (2003) Carbon isotope constraints on vertical mixing and air-sea $\mathrm{CO}_{2}$ exchange. Geophys Res Lett 30:2289. https://doi.org/ 10.1029/2003GL018049

Fallon SJ, McCulloch MT, Guilderson TP (2005) Interpreting environmental signals from the coralline sponge Astrosclera willeyana. Palaeogeogr Palaeoclimatol Palaeoecol 228:58-69. https://doi.org/10.1016/j.palaeo.2005.03.053

Felis T, Pätzold J, Loya Y (2003) Mean oxygen-isotope signatures in Porites spp. corals: inter-colony variability and correction for extension-rate effects. Coral Reefs 22:328-336 https://doi.org/10.1007/s00338-003-0324-3 
Gabitov Rl, Gaetani GA, Watson EB, Cohen AL, Ehrlich HL (2008) Experimental determination of growth rate effect on $\mathrm{U}^{6+}$ and $\mathrm{Mg}^{2+}$ partitioning between aragonite and fluid at elevated $\mathrm{U}^{6+}$ concentration. Geochim Cosmochim Acta 72:4058-4068. https://doi.org/10.1016/j.gca.2008.05.047

Gaetani GA, Cohen AL (2006) Element partitioning during precipitation of aragonite from seawater: a framework for understanding paleoproxies. Geochim Cosmochim Acta 70:4617-4634. https://doi.org/10.1016/j.gca.2006.07.008

Gilis M, Grauby O, Willenz P, Dubois P, Heresanu V, Baronnet A (2013) Biomineralization in living hypercalcified demosponges: toward a shared mechanism? J Struct Biol 183:441-454 https://doi.org/10.1016/j.jsb.2013.05.018

Gonneea ME, Cohen AL, DeCarlo TM, Charette MA (2017) Relationship between water and aragonite barium concentrations in aquaria reared juvenile corals. Geochim Cosmochim Acta 209:123-134 https://doi.org/10.1016/j.gca.2017.04.006

Grottoli AG (2006) Monthly resolved stable oxygen isotope record in a Palauan sclerosponge Acanthocheatetes wellsi for the period of 1977-2001. In Proc 10th Int Coral Reef Symp 2004:572-579.

Grottoli AG, Adkins JF, Panero WR, Reaman DM, Moots K (2010) Growth rates, stable oxygen isotopes $\left(\delta^{18} \mathrm{O}\right)$, and strontium ( $\left.\mathrm{S} r / \mathrm{Ca}\right)$ composition in two species of Pacific sclerosponges (Acanthocheatetes wellsi and Astrosclera willeyana) with $\delta^{18} \mathrm{O}$ calibration and application to paleoceanography. J Geophys Res 115:C06008. https://doi.org/10.1029/2009JC005586

Haase-Schramm A, Böhm F, Eisenhauer A, Garbe-Schönberg D, Dullo W-C, Reitner J (2005) Annual to interannual temperature variability in the Caribbean during the Maunder sunspot minimum. Paleoceanography 20:PA4015. https://doi.org/10.1029/2005PA001137

Hartman WD (1980) Ecology of recent sclerosponges. In: Hartman WD, Wendt JW, Wiedenmayer F (eds.) Living and Fossil Sponges. Sedimenta, Miami, pp 253-255.

Hartman WD, Goreau TF (1966) Ceratoporella, a living sponge with stromatoporoid affinities. Am Zool 6:563-564

Hathorne EC et al (2013) Interlaboratory study for coral Sr/Ca and other element/ Ca ratio measurements. Geochem Geophys Geosyst 14:3730-3750. https:// doi.org/10.1002/ggge.20230

Jackson DJ, Thiel V, Wörheide G (2010) An evolutionary fast-track to biocalcification. Geobiology 8:191-196 https://doi.org/10.1111/j.1472-4669. 2010.00236.x

Keeling CD, Mook WG, Tans PP (1979) Recent trends in the ${ }^{13} \mathrm{C} /{ }^{12} \mathrm{C}$ ratio of atmospheric carbon dioxide. Nature 277:121-123. https://doi.org/10.1038/ $277121 \mathrm{a} 0$

Kim S-T, O'Neil JR, Hillaire-Marcel C, Mucci A (2007) Oxygen isotope fractionation between synthetic aragonite and water: influence of temperature and $\mathrm{Mg}^{2+}$ concentration. Geochim Cosmochim Acta 71:4704-4715. https://doi.org/10. 1016/j.gca.2007.04.019

Kinsman DJ, Holland HD (1969) The co-precipitation of cations: IV. The coprecipitation of $\mathrm{Sr}^{2+}$ with aragonite between $16-96^{\circ} \mathrm{C}$. Geochim Cosmochim Acta 33:1-17 https://doi.org/10.1016/0016-7037(69)90089-1

Langmuir D (1978) Uranium solution-mineral equilibria at low temperatures with applications to sedimentary one deposits. Geochim Cosmochim Acta 42: 547-569 https://doi.org/10.1016/0016-7037(78)90001-7

Lazareth C, Willenz P, Navez J, Keppens E, Dehairs F, Andre L (2000) Sclerosponges as a new potential recorder of environmental changes: lead in Ceratoporella nicholsoni. Geology 28:515-518, doi:10.1130/00917613(2000) 28 < 515:SAANPR> 2.0.CO;2

Lister JJ (1900) Astrosclera willeyana, the type of a new family of sponges. Zool Res 4:461-482

Mavromatis V, Goetschl KE, Grengg C, Konrad F, Purgstaller B, Dietzel M (2018) Barium partitioning in calcite and aragonite as a function of growth rate. Geochim Cosmochim Acta 237:65-78 https://doi.org/10.1016/j.gca.2018.06.018

McConnaughey TA (1989) ${ }^{13} \mathrm{C}$ and ${ }^{18} \mathrm{O}$ isotopic disequilibrium in biological carbonates: I. Patterns. Geochim Cosmochim Acta 53:151-162. https://doi. org/10.1016/0016-7037(89)90282-2

McConnaughey TA (2003) Sub-equilibrium oxygen-18 and carbon-13 levels in biological carbonates: carbonate and kinetic models. Coral Reefs 22:316-327 https://doi.org/10.1007/s00338-003-0325-2

Min GR, Edwards RL, Taylor FW, Recy J, Gallup CD, Beck JW (1995) Annual cycles of $\mathrm{U} / \mathrm{Ca}$ in coral skeletons and $\mathrm{U} / \mathrm{Ca}$ thermometry. Geochim Cosmochim Acta 59:2025-2042 https://doi.org/10.1016/0016-7037(95)00124-7

Moore MD, Charles CD, Rubenstone JL, Fairbanks RG (2000) U/Th-dated sclerosponges from the Indonesian Seaway record subsurface adjustments to west Pacific winds. Paleoceanography 15:404-416. https://doi.org/10.1029/ 1999PA000396
Nakayama H, lijima H, Nakamura N, Kayanne H (2008) Carbon and oxygen stable isotope ratios of GSJ carbonate reference materials (JCp-1 and JCt-1). Bull Geol Surv Japan 59:461-466 (in Japanese with English abstract)

Naruse T, Chan TY, Tan HH, Ahyong ST, Reimer JD (2012) Scientific results of the Kumejima marine biodiversity expedition—KUMEJIMA 2009. Zootaxa 3367:1-280

Oba T (1990) Paleoceanographic information obtained by the isotopic measurement of individual foraminiferal specimens. In: Wang P, Lao Q, He Q (eds) Asian Marine Geology. China Ocean Press, Beijing, pp 169-180

Ohmori K, Watanabe T, Tanimizu M, Shirai K (2014) Lead concentration and isotopic composition in the Pacific sclerosponge (Acanthochaetetes wellsi) reflects environmental lead pollution. Geology 42:287-290. https://doi.org/10. $1130 / G 34316.1$

Okai T, Suzuki A, Kawahata H, Terashima S, Imai N (2002) Preparation of a new Geological Survey of Japan geochemical reference material: coral JCp-1. Geostand Newslett 26:95-99 https://doi.org/10.1111/j.1751-908X.2002. tb00627.x

Okai T, Suzuki A, Terashima S, Inoue M, Nohara M, Kawahata H, Imai N (2004) Collaborative analysis of GSJ/AIST geochemical reference materials JCp1 (Coral) and JCt-1(Giant Clam). Chikyu Kagaku (Geochemistry) 38:281-286 https://doi.org/10.14934/chikyukagaku.38.281 (in Japanese with English abstract)

PAGES $2 \mathrm{k}$ Consortium (2013) Continental-scale temperature variability during the past two millennia. Nat Geosci 6:339-346. https://doi.org/10.1038/ngeo1797

Poulain C, Gillikin DP, Thebault J, Munaron JM, Bohn M, Robert R, Paulet Y-M, Lorrain A (2015) An evaluation of $\mathrm{Mg} / \mathrm{Ca}, \mathrm{Sr} / \mathrm{Ca}$, and $\mathrm{Ba} / \mathrm{Ca}$ ratios as environmental proxies in aragonite bivalve shells. Chem Geol 396:42-50 https://doi.org/10.1016/j.chemgeo.2014.12.019

Quay PD, Tilbrook B, Wong CS (1992) Oceanic uptake of fossil fuel $\mathrm{CO}_{2}$ : carbon13 evidence. Science 256:74-79. https://doi.org/10.1126/science.256.5053.74

Reitner J (1992) "Coralline Spongien". Der Versuch einer phylogenetischtaxonomischen Analyse. Coralline sponges an attempt of a phylogenetictaxonomic analysis. Berliner Geowiss. Abh. Reihe E Palaeobiol 1:1-352

Reitner J, Engeser TS (1987) Skeletal structures and habitats of recent and fossil Acanthochaetetes (subclass Tetractinomorpha, Demospongiae, Porifera). Coral Reefs 6:13-18. https://doi.org/10.1007/BF00302207

Reitner J, Gautret P (1996) Skeletal formation in the modern but ultraconservative chaetetid sponge Spirastrella (Acanthochaetetes) wellsi (Demospongiae, Porifera). Facies 34:193-208. https://doi.org/10.1007/BF02546164

Reynolds RW, Rayner NA, Smith TM, Stokes DC, Wang W (2002) An improved in situ and satellite SST analysis for climate. J Clim 15:1609-1625 https://doi.org/ 10.1175/1520-0442(2002)015<1609:AllSAS>2.0.CO;2

Romanek CS, Grossman EL, Morse JW (1992) Carbon isotopic fractionation in synthetic aragonite and calcite: effects of temperature and precipitation rate. Geochim Cosmochim Acta 56:419-430 https://doi.org/10.1016/00167037(92)90142-6

Rosenheim BE, Swart PK, Thorrold SR (2005b) Minor and trace elements in sclerosponge Ceratoporella nicholsoni: biogenic aragonite near the inorganic endmember? Palaeogeogr Palaeoclimatol Palaeoecol 228:109-129 https:// doi.org/10.1016/j.palaeo.2005.03.055

Rosenheim BE, Swart PK, Thorrold SR, Eisenhauer A, Willenz P (2005a) Salinity change in the subtropical Atlantic: secular increase and teleconnections to the North Atlantic Oscillation. Geophys Res Lett 32:L02603. https://doi.org/10. 1029/2004GL021499

Rosenheim BE, Swart PK, Thorrold SR, Willenz P, Berry L, Latkoczy C (2004) Highresolution $\mathrm{Sr} / \mathrm{Ca}$ records in sclerosponges calibrated to temperature in situ. Geology 32(2):145-148 https://doi.org/10.1130/G20117.1

Rosenheim BE, Swart PK, Willenz P (2009) Calibration of sclerosponge oxygen isotope records to temperature using high-resolution $\delta^{18} \mathrm{O}$ data. Geochim Cosmochim Acta 73:5308-5319. https://doi.org/10.1016/.gca.2009.05.047

Shen GT, Dunbar RB (1995) Environmental controls on uranium in reef corals. Geochim Cosmochim Acta 59:2009-2024 https://doi.org/10.1016/00167037(95)00123-9

Suzuki A, Kawamura N, Itaki T, Katayama H, Murakami S, Usami T, Kuroyanagi A (2009) Geochemical analyses on seawater samples collected during the GH08 cruise in the eastern offshore of Okinawa Island. In: Arak K (ed) Marine Geological and Geophysical Studies around Okinawa Islands eastern off of Okinawa Island, Preliminary Reports on Researches in the 2008 Fiscal Year, GSJ Interim Rep 46. Geol Surv Jpn, Natl Inst Adv Ind Sci and Technol, Tsukuba, pp 86-92

Swart PK, Greer L, Rosenheim BE, Moses CS, Waite AJ, Winter A, Dodge RE, Helmle K (2010) The ${ }^{13} C$ Suess effect in scleractinian corals mirror changes in 
the anthropogenic $\mathrm{CO}_{2}$ inventory of the surface oceans. Geophys Res Lett 37:L05604. https://doi.org/10.1029/2009GL041397

Swart PK, Thorrold S, Rosenheim B, Eisenhauer A, Harrison CGA, Grammer M, Latkoczy C (2002) Intra-annual variation in the stable oxygen and carbon and trace element composition of sclerosponges. Paleoceanography 17:1045. https://doi.org/10.1029/2000PA000622

Takayanagi H, Asami R, Abe O, Miyajima T, Kitagawa H, Iryu Y (2012) Carbon- and oxygen-isotope compositions of a deep-water modern brachiopod Campagea japonica collected off Aguni-jima, Central Ryukyu Islands, southwestern Japan. Geochem J 46:77-87 https://doi.org/10.2343/geochemj. 1.0153

Uemura R, Yonezawa N, Yoshimura K, Asami R, Kadena H, Yamada K, Yoshida N (2012) Factors controlling isotopic composition of precipitation on Okinawa Island, Japan: implications for paleoclimate reconstruction in the East Asian Monsoon region. J Hydrol 475:314-322 https://doi.org/10.1016/j.jhydrol.2012. 10.014

Vacelet J (1979) Description et affinit.s d'une .ponge actuelle. In: Levi C, BouryEsnault N (eds) Biologie des Spongiaires - sponge biology. Colloques Internationaux du Centre National de la Recherche Scientifique, CNRS, Paris, pp 483-493

Vacelet J (1985) Coralline sponges and the evolution of Porifera. In: Conway Morris S, George JD, Gibson R, Platt HM (eds) The Origins and Relationships of Lower Invertebrates. Clarendon Press, Oxford, pp 1-13

Waite AJ, Swart PK, Rosenheim BE, Rosenberg AD (2018) Improved calibration of the $\mathrm{Sr} / \mathrm{Ca}$-temperature relationship in the sclerosponge Ceratoporella nicholsoni: Re-evaluating $\mathrm{Sr} / \mathrm{Ca}$ derived records of post-industrial era warming. Chem Geol 488:56-61 https://doi.org/10.1016/j.chemgeo.2018.03. 005

Wassenburg JA, Scholz D, Jochum KP, Cheng H, Oster J, Immenhauser A, Richter DK, Hager T, Jamieson RA, Baldini JUL, Hoffmann D, Breitenbach SFM (2016) Determination of aragonite trace element distribution coefficients from speleothem calcite-aragonite transitions. Geochim Cosmochim Acta 190:347367 https://doi.org/10.1016/j.gca.2016.06.036

Willenz P, Hartman WD (1989) Micromorphology and ultrastructure of Caribbean sclerosponges. Mar Biol 103:387-401 https://doi.org/10.1007/BF00397274

Wood R (1990) Reef-building sponges. Am Sci 78:224-235

Wörheide G (1998) The reef cave dwelling ultraconservative coralline demosponge Astrosclera willeyana Lister 1900 from the Indo-Pacific. Micromorphology, ultrastructure, biocalcification, isotope record, taxonomy, biogeography, phylogeny. Facies 38:1-88. https://doi.org/10.1007/ BF02537358

Wörheide G, Reitner J, Gautret P (1997) Comparison of biocalcification processes in the two coralline demosponges Astrosclera willeyana Lister 1900 and "Acanthochaetetes" wellsi Hartman and Goreau 1975. In: Lessios HA, Macintyre IG (eds) Proc 8th Int Coral Reef Symp. Smithsonian Tropical Research Institute, Panama, pp 1427-1432

Wu HC, Grottoli AG (2010) Stable oxygen isotope records of corals and a sclerosponge in the Western Pacific warm pool. Coral Reefs 29:413-418 https://doi.org/10.1007/s00338-009-0576-7

Zhang J, Quay PD, Wilbur DO (1995) Carbon isotope fractionation during gaswater exchange and dissolution of $\mathrm{CO}_{2}$. Geochim Cosmochim Acta 59:107114 https://doi.org/10.1016/0016-7037(95)91550-D

\section{Publisher's Note}

Springer Nature remains neutral with regard to jurisdictional claims in published maps and institutional affiliations.

\section{Submit your manuscript to a SpringerOpen ${ }^{\circ}$ journal and benefit from:}

- Convenient online submission

- Rigorous peer review

- Open access: articles freely available online

- High visibility within the field

- Retaining the copyright to your article

Submit your next manuscript at $\boldsymbol{\nabla}$ springeropen.com 